\title{
Isolation, identification and expression analysis of salt-induced genes in Suaeda maritima, a natural halophyte, using PCR-based suppression subtractive hybridization Binod B Sahu* and Birendra P Shaw
}

Address: Environmental Biotechnology Laboratory, Institute of Life Sciences, Nalco Square, Bhubaneswar, PIN-751023, India

Email: Binod B Sahu* - binodbiharisahu@gmail.com; Birendra P Shaw - b_p_shaw@yahoo.com

* Corresponding author

Published: 5 June 2009

BMC Plant Biology 2009, 9:69 doi:10.1 186/147/-2229-9-69
Received: 12 january 2009

Accepted: 5 June 2009

This article is available from: http://www.biomedcentral.com/I47/-2229/9/69

(C) 2009 Sahu and Shaw; licensee BioMed Central Ltd.

This is an Open Access article distributed under the terms of the Creative Commons Attribution License (http://creativecommons.org/licenses/by/2.0), which permits unrestricted use, distribution, and reproduction in any medium, provided the original work is properly cited.

\begin{abstract}
Background: Despite wealth of information generated on salt tolerance mechanism, its basics still remain elusive. Thus, there is a need of continued effort to understand the salt tolerance mechanism using suitable biotechnological techniques and test plants (species) to enable development of salt tolerant cultivars of interest. Therefore, the present study was undertaken to generate information on salt stress responsive genes in a natural halophyte, Suaeda maritima, using PCR-based suppression subtractive hybridization (PCR-SSH) technique.
\end{abstract}

Results: Forward and reverse SSH cDNA libraries were constructed after exposing the young plants to $425 \mathrm{mM} \mathrm{NaCl}$ for $24 \mathrm{~h}$. From the forward SSH cDNA library, 429 high quality ESTs were obtained. BLASTX search and TIGR assembler programme revealed overexpression of 167 unigenes comprising 89 singletons and 78 contigs with ESTs redundancy of $81.8 \%$. Among the unigenes, $32.5 \%$ were found to be of special interest, indicating novel function of these genes with regard to salt tolerance. Literature search for the known unigenes revealed that only 17 of them were salt-inducible. A comparative analysis of the existing SSH cDNA libraries for $\mathrm{NaCl}$ stress in plants showed that only a few overexpressing unigenes were common in them. Moreover, the present study also showed increased expression of phosphoethanolamine $\mathrm{N}$-methyltransferase gene, indicating the possible accumulation of a much studied osmoticum, glycinebetaine, in halophyte under salt stress. Functional categorization of the proteins as per the Munich database in general revealed that salt tolerance could be largely determined by the proteins involved in transcription, signal transduction, protein activity regulation and cell differentiation and organogenesis.

Conclusion: The study provided a clear indication of possible vital role of glycinebetaine in the salt tolerance process in S. maritima. However, the salt-induced expression of a large number of genes involved in a wide range of cellular functions was indicative of highly complex nature of the process as such. Most of the salt inducible genes, nonetheless, appeared to be species-specific. In light of the observations made, it is reasonable to emphasize that a comparative analysis of ESTs from SSH cDNA libraries generated systematically for a few halophytes with varying salt exposure time may clearly identify the key salt tolerance determinant genes to a minimum number, highly desirable for any genetic manipulation adventure. 


\section{Background}

Abiotic stresses are the principal cause of decreasing the average yield of major crops by more than $50 \%$ leading to losses worth hundreds of million dollars each year [1]. Among these, high soil salinity, contributed largely by $\mathrm{Na}^{+}$ and often compounded with drought, is the main factor that adversely limits the growth and productivity of the major crop plants, including rice. Nevertheless, plants do exist in nature, like the halophytes, which survive and grow under extreme of salinity; severe climate changes throughout millions of years have resulted in the evolution of flora that exhibit substantial genetic diversity for adaptation to environmental perturbations [2]. It is in fact also believed that the genetic diversity in glycophyte, particularly in the crop plants, has been narrowed down over the millennia because of loss of alleles contributing significantly to salt adaptability [2]. Hence, while there is a need to understand the plants' response to salt stress, and the salt tolerance mechanism itself, with the common aim of enhancing salt tolerance in the crop plants, it is necessary that such attempt should include preferably the halophytic species. This is required, as variation in salt tolerance in the crop plants is relatively small, although working with the crop species has direct implication for agriculture.

Decades of research on the effect of salinity on growth and development of various plants and their response to salinity treatment at the physiological and biochemical levels has generated a wealth of information on the salt tolerance related parameters or salt tolerance determinants in plants. These may be grouped into 1) morphology adaptation, reflected as thickening of the leaves and cuticular wax deposition [3], 2) osmotic adjustment, reflected as accumulation of compatible solutes in the cytoplasm [4], 3 ) maintenance of ion homeostasis, reflected as $\mathrm{H}^{+}$-pump functioning [5], $\mathrm{K}^{+} / \mathrm{Na}^{+}$selectivity [6] and $\mathrm{Na}^{+}$exclusion and compartmentation [7-9], 4) cell signalling and gene expression, reflected as abscisic acid (ABA) and jasmonic acid (JA) accumulation $[10,11]$, regulation of salt overly sensitive gene-1, SOS1 [12,13], $\mathrm{Ca}^{2+-i n d u c e d ~ i n c r e a s e ~ i n ~}$ $\mathrm{K}^{+} / \mathrm{Na}^{+}$selectivity [14], increase in $\operatorname{CDPK}\left(\mathrm{Ca}^{2+-d e p e n d e n t}\right.$ protein kinase) and MAPK (mitogen-activated protein kinase) activities $[15,16]$ and synthesis of many transcription factors [15,17-19], 5) oxidative stress mitigation, reflected as activation of the antioxidative machinery $[20,21]$, and 6) molecular trafficking and cell stability, reflected as the accumulation of heat-shock proteins (HSPs), jasmonic acid-induced proteins (JAIPs) and late embryogenesis abundant (LEA) proteins [15,17,22-25]. Although transgenic plants have been developed for many genes upregulated under salt stress, such as P5CS ( $\Delta^{1}$-pyrroline-5-carboxylate synthetase), DNA helicase, carbonic anhydrase (CA), glyceraldehydes-3-phosphate dehydrogenase, $\mathrm{Na}^{+} / \mathrm{H}^{+}$antiporter [26-30], and the plants show enhanced tolerance to salinity, the field trials of many of them have remained highly unsuccessful [31]. Hence, the basics of salt tolerance still remain illusive, and needs further investigation.

The plant stress adaptive responses include dynamic transcriptome changes, presumably playing important role in co-ordination of the many different molecular events responsible for cellular and organismal homeostasis. These changes are generally regulated by complex signalling pathways, which are activated in response to various abiotic and biotic stimuli allowing the plants to cope with the changing environmental conditions [32]. There also occurs crosstalk between different signalling pathways $[33,34]$, and identification of the convergent and divergent pathways between salinity and other abiotic stress responses and the nodes of signalling convergence may greatly enhance the understanding of the salinity stress response and the salt tolerance mechanism. Although several studies have been carried out on abiotic stress responsive signal pathways [15,35-37], and several reports exist on massive changes in the profile of gene expression in plants [38,39], these are mostly on Arabidopsis or other glycophytes, which are sensitive to salt. Such studies on the native flora of saline environment, i.e. halophytes, are scarce, although better information on the salt tolerance determinants is likely to come from the work on these plants rather than the work on the glycophytes.

One of the techniques being largely used to identify stressresponsive genes is subtractive hybridization. Attempts have been made to identify the salt stress regulated genes by suppression subtractive hybridization ( $\mathrm{SSH}$ ) in rice [19] and tomato [18]. However, to the best of our knowledge, the technique has so far not been used to identify the genes differentially expressing under salt stress in salttolerant plants. Among the salt-tolerant photosynthetic organisms, nevertheless, the salt-stress upregulated ESTs have been cloned in an alga, Dunaliella salina [40]. However, only a few highly upregulated ESTs were sequenced for further studies. Hence, the present work was carried out with the aim of generating cDNA library of saltinduced genes in S. maritima, a natural halophyte, following PCR based SSH in order to get information on salt stress response in the plant at the transcript level. Moreover, most of the salt-stress upregulated ESTs were identified so as to get a comprehensive picture of the salt-stress response in the plant at the level of gene, which might be useful in elucidating the molecular mechanism underlying salt tolerance.

\section{Methods \\ Test plant and stress application}

Seeds of Suaeda maritima L. were collected from the adult plants growing along the mangrove coastal belt in Orissa, 
India. The surface-sterilized seeds were soaked in de-ionized (Milli-Q) water overnight, transferred over wet filter paper in a petriplate and kept at $25^{\circ} \mathrm{C}$ for germination. It took approximately six days for the cotyledonary leaves to emerge fully. The germinated seeds were transferred over net, which remained in touch with half-strength Hoagland's solution contained in $150 \mathrm{ml}$ plastic beakers. The Hoagland's solution contained $5.0 \mathrm{mM} \mathrm{KNO}_{3}, 7.0 \mathrm{mM}$ $\mathrm{Ca}\left(\mathrm{NO}_{3}\right)_{2}, 2 \mathrm{mM} \mathrm{MgSO}_{4}, 2 \mathrm{mM} \mathrm{KH}_{2} \mathrm{PO}_{4}, 26 \mu \mathrm{M}$ Fe-EDTA (Ethylenediaminetetraacetic acid Fe-salt), $45 \mu \mathrm{M} \mathrm{H}_{3} \mathrm{BO}_{3}$, $0.4 \mu \mathrm{M} \mathrm{CuSO}_{4}, 0.7 \mu \mathrm{M} \mathrm{ZnSO}_{4}, 9.1 \mu \mathrm{M} \mathrm{MnCl}_{2}, 28 \mathrm{mM}$ $\mathrm{FeSO}_{4}$ and $0.1 \mu \mathrm{M}\left(\mathrm{NH}_{4}\right)_{6} \mathrm{Mo}_{7} \mathrm{O}_{24}(\mathrm{pH} 5.7$, adjusted with $1 \mathrm{M} \mathrm{KOH})$. The seedlings were allowed to grow hydroponically in a growth chamber maintained at $24 \pm 3{ }^{\circ} \mathrm{C}, 70-$ $75 \%$ relative humidity and $14 \mathrm{~h}$ light $\left(200 \mu \mathrm{mol} \mathrm{m}^{-2} \mathrm{~s}^{-1}\right) /$ $10 \mathrm{~h}$ dark cycle. The level of the medium was maintained by adding Milli-Q water. After 20 days, the seedlings were approximately $2 \mathrm{~cm}$ in height. At this stage, the seedlings were transferred to soil in plastic pots of known volume. The seedlings were set to acclimatize and grow for $\sim 3$ weeks under natural day/night cycle in a green house maintained at $24 \pm 3{ }^{\circ} \mathrm{C}$ and $70-75 \%$ relative humidity. During this period, the seedling attained a height of $\sim 6 \mathrm{~cm}$ with lateral branches. The individual pots were watered every day alternately with approximately $150 \mathrm{ml}$ of $1 / 10^{\text {th }}$ Hoagland's solution or Milli-Q water except on the penultimate day of the stress application. For the stress application, initially $100 \mathrm{ml}$ of $0.5 \% \mathrm{NaCl}$, prepared in $1 / 10^{\text {th }}$ strength Hoagland's solution, was poured into the individual pots in the evening. The control pots received only Milli-Q water. After incubation for $1 \mathrm{~h}$, another $150 \mathrm{ml}$ of $1 / 10^{\text {th }}$ strength Hoagland's solution containing $5.75 \mathrm{~g}$ $\mathrm{NaCl}$ was poured into the treatment pots, raising their final $\mathrm{NaCl}$ treatment concentration (in $250 \mathrm{ml}$ treatment volume) to $425 \mathrm{mM}$. It was determined earlier that $100 \mathrm{ml}$ water was completely absorbed by the soil in the pot, while the additional $150 \mathrm{ml}$ was partly absorbed and the rest inundated the soil. After $24 \mathrm{~h}$ of the initial $\mathrm{NaCl}$ treatment, the leaves of the seedlings were harvested, and were preserved in liquid $\mathrm{N}_{2}$ until further analysis. The leaves from the control plants were also preserved similarly. The treatment duration was determined based on the observation that the activity of the plasma membrane (PM) $\mathrm{H}^{+}$ATPase, involved in the maintenance of ion homeostasis, increased to a maximum in $30-36 \mathrm{~h}$ of the initial $\mathrm{NaCl}$ treatment. Although change in transcription, both quantitative and qualitative, in a plant can be noticed in less than half an hour of change in the environmental condition, a long duration exposure $(24 \mathrm{~h})$ of the plant to $\mathrm{NaCl}$ was preferred thinking that it would provide information about those genes that are really needed for adaptation of plants to saline environment in long run. Moreover, as the time gap between transcription and translation is generally $3 \mathrm{~h}$ or more, it was decided to go for RNA extraction after exposure (to $\mathrm{NaCl}$ ) of the plant for $24 \mathrm{~h}, 6 \mathrm{~h}$ ahead of the exposure time at which the enzyme (PM-H+ATPase) activity reached to the maximum.

\section{RNA isolation and CDNA preparation}

Total RNA was isolated from the leaves of control and 425 $\mathrm{mM} \mathrm{NaCl}$ exposed plants following $\mathrm{LiCl}$ method [41]. mRNA was purified from the total RNA isolated using PolyATtract $^{\circledast}$ mRNA Isolation System I (Promega, USA) following the protocol supplied along with the kit. Double stranded cDNA was prepared by reverse transcription of 4 $\mu \mathrm{g}$ of the purified mRNA in $20 \mu \mathrm{l}$ reaction solution following the steps outlined in the cDNA preparation kit (Super SMART PCR cDNA synthesis kit, Clontech, Palo alto, USA). The total RNA isolated from the leaves of both the control and NaCl-treated plants were processed simultaneously for the mRNA purification and cDNA preparation.

\section{Construction of SSH cDNA libraries}

The SSH (Suppression Subtractive Hybridization) cDNA libraries, forward and reverse, were prepared using PCRselect-cDNA SSH kit (Clontech, Palo alto, USA). For this, the double stranded cDNAs prepared from the control and $\mathrm{NaCl}$ treated samples were digested separately with RsaI for $1.5 \mathrm{~h}$ to produce blunt ends. The digested products were extracted with phenol:chloroform:isoamyl alcohol (25:24:1), followed by extraction of the resulting aqueous phase with chloroform:isoamyl alcohol (24:1) twice. Finally, the digested cDNAs in the upper aqueous phase were ethanol precipitated and resuspended in nuclease free water (Promega, USA). The RsaI digested cDNAs of the control (C) and NaCl-treated (T) samples were divided into 4 equal parts. One part each of the $\mathrm{C}$ and $\mathrm{T}$ cDNA populations were ligated separately with adapter-1 (supplied in the SSH kit) at the $5^{\prime}$ end in the reactions carried out overnight at $16^{\circ} \mathrm{C}$, and the ligated products were called CA1 (Rsal digested cDNA population of control sample with adapter-1) and TA1 (RsaI digested cDNA population of $\mathrm{NaCl}$-treated sample with adapter-1), respectively. Another part each of the $C$ and $T$ CDNA populations were ligated with adaptor-2R (supplied in the SSH kit) at the $5^{\prime}$ end in a similar fashion, and were called respectively C2R (RsaI digested cDNA population of control sample with adapter-2R) and T2R (RsaI digested cDNA population of $\mathrm{NaCl}$-treated sample with adapter-2R). The ligation of both the adaptors was checked by PCR amplification of the actin gene using actin gene-specific reverse primer (5'TTGCATCACTCAGCACCTTC) and adapter-specific forward primer (provided in the SSH kit). The remaining two parts of both $\mathrm{C}$ and $\mathrm{T}$, representing the Rsal digested cDNA population with blunt end of the control and $\mathrm{NaCl}$-treated samples, respectively were kept as such. 
To create the forward SSH cDNA library, which would represent enriched population of the overexpressed and newly induced transcript messages, TA1 and T2R were considered as 'Tester-A' and 'Tester-B', respectively, and the $\mathrm{C}$ as the 'Driver'. The opposite was the case for the creation of the reverse SSH cDNA library representing enriched population of the down-regulated transcripts, i.e. CA1 and C2R were considered as 'Tester-A' and 'Tester$\mathrm{B}$ ', respectively, and the $\mathrm{T}$ as the 'Driver'. Two rounds of hybridization were performed. In the first round, the denatured 'Tester-A' and 'Tester-B' were mixed separately with excess of the denatured 'Driver'. This resulted in subtraction of the cDNAs representing the less or equally abundant transcripts in the 'Tester' source (the sample considered as 'Tester') compared to that in the 'Driver' source (the sample considered as 'Driver'). Besides, this also resulted in the formation of single stranded cDNAs having adapter-1 (in the case when the 'Tester A' cDNA population was hybridized with the 'Driver') or adapter$2 \mathrm{R}$ (in the case when the 'Tester B' cDNA population was hybridized with the 'Driver'). These represented the transcripts not present in the 'Driver' source or present in greater number in the 'Tester' source than that in the 'Driver' source. In the second round of hybridization, the 'Tester-A' and 'Tester-B', hybridized previously with the excess of 'Driver' separately, were mixed together without denaturing, followed by mixing with excess of the denatured 'Driver'. This resulted in the formation of hybrid double stranded cDNA (one strand having adaptor- 1 and the other strand having adaptor $2 \mathrm{R}$ at the 5 ' end) for those transcripts present only in the 'Tester' source or present in greater number in the 'Tester' source than that in the 'Driver' source. Two rounds of PCR were carried out with two different sets of primers specific to the two adaptors (supplied in the SSH kit) to exponentially amplify the hybrid CDNAs. The primary PCR was performed with one set of primers for 27 cycles $\left(94^{\circ} \mathrm{C}\right.$ for 3 minute followed by 27 cycles of $94^{\circ} \mathrm{C}$ for 30 seconds, $50^{\circ} \mathrm{C}$ for 30 seconds and $72^{\circ} \mathrm{C}$ for 45 seconds, and finally incubation at $72^{\circ} \mathrm{C}$ for 10 minutes and storage at $4^{\circ} \mathrm{C}$ forever). This was referred as the forward or the reverse subtracted SSH cDNA (library), as the case may be. The secondary PCR was performed with the other set of primers for 20 cycles maintaining the same conditions using ten-fold diluted product of the primary PCR. The secondary PCR products of the forward and the reverse SSH cDNA libraries were purified using Qiagen column, cloned into pGEMT EasyVector (Promega, USA) and transformed into JM109 E. coli competent cells.

The transformed bacteria for both the forward and the reverse SSH cDNA libraries were plated separately on four LB agar plates ( $15 \mu \mathrm{l} \mathrm{SSH} \mathrm{cDNA} \mathrm{each} \mathrm{plate),} \mathrm{incubated} \mathrm{at}$ $37^{\circ} \mathrm{C}$ for $24 \mathrm{~h}$, and the white colonies were picked-up. Approximately 500 colonies from both the forward and the reverse SSH libraries could be picked-up. These colonies were grown individually in liquid LB medium at $37^{\circ} \mathrm{C}$ overnight at $200 \mathrm{rpm}$ in 96 well plates. The medium contained $10 \%$ glycerol to facilitate long period storage. Inoculums of the individual culture were then grown in 2 $\mathrm{ml}$ of the same medium (supplemented with $100 \mu \mathrm{g} \mathrm{ml}^{-1}$ ampicillin) at $37^{\circ} \mathrm{C}$ and $200 \mathrm{rpm}$ overnight. The plasmids were isolated using Qiaprep Spin Mini-Prep kit (Qiagen, $\mathrm{GmbH}$ ) as per the manufacturer's protocol.

\section{Screening and authentication of the SSH libraries}

Randomly selected 150 plasmid samples of each library were spotted (approximately $50 \mathrm{ng}$ plasmid DNA each spot) separately on $8 " \times 10$ " nylon membrane $\left(\mathrm{N}^{+}\right.$, Amersham Hybond) in duplicate. The secondary PCR products (100 ng, prepared afresh) of the forward and the reverse SSH cDNA libraries were labelled separately with $\alpha-32 \mathrm{P}-$ dATP by random primer labelling as per the instruction of the SSH screening kit (PCR-select screening kit, Clontech), and purified by BioRad spin-30 column (Bio-Rad, USA). The plasmid spotted membranes were incubated separately for half an hour in $30 \mathrm{ml}$ prehybridization buffer (7\% SDS and $10 \mathrm{mM}$ Na-EDTA in $0.5 \mathrm{M}$ sodium phosphate buffer, $\mathrm{pH} 7.2$ ) at $65^{\circ} \mathrm{C}$ in $300 \mathrm{~mm} \times 35 \mathrm{~mm}$ hybridization bottles. The buffer in each bottle was replaced with $30 \mathrm{ml}$ of fresh prehybridization buffer, maintained at $65^{\circ} \mathrm{C}$. The desired denatured probe was added to the individual bottles and hybridization was allowed to continue overnight at $65^{\circ} \mathrm{C}$. One of the two membranes spotted with the plasmids from the forward SSH cDNA library was hybridized with the probe prepared from the secondary PCR product of the forward SSH cDNA library and the other with the probe prepared from the secondary PCR product of the reverse SSH CDNA library. Similarly, one of the two membranes spotted with the plasmids from the reverse SSH cDNA library was hybridized with the probe prepared from the forward SSH cDNA library and the other with probe prepared from the reverse SSH cDNA library. After the hybridization reaction, the membranes were washed with $30 \mathrm{ml}$ of wash buffer-I $(1 \times$ SSC, pH 7.0 containing $150 \mathrm{mM} \mathrm{NaCl}, 15$ $\mathrm{mM} \mathrm{Na}_{3}$ Citrate. $2 \mathrm{H}_{2} \mathrm{O}$ and $0.1 \% \mathrm{SDS}$ ) for $30 \mathrm{~min}$ at $65^{\circ} \mathrm{C}$ followed by washing with $30 \mathrm{ml}$ of wash buffer-II $(0.5 \times$ SSC and $0.1 \%$ SDS) at $65^{\circ} \mathrm{C}$ for $15 \mathrm{~min}$. The membranes were air-dried and exposed to X-ray film at $-70^{\circ} \mathrm{C}$ overnight, and developed.

\section{Sequencing and analysis of the cloned ESTs}

The plasmid inserts of only the forward SSH cDNA library were considered for sequencing. The plasmids purified by Qiagen mini-prep plasmid kit were sent for single pass sequencing at The Centre for Genomic Application (TCGA, New Delhi) with $\mathrm{SP}_{6}$ as the forward primer. The sequences obtained were fed into VecScreen software (NCBI) to remove the vector sequence contaminations. 
The sequences of the adaptors were removed manually. The expressed sequence tags (ESTs) of approximately 100 bp or more in length were only considered for further analysis. The EST sequences were grouped into singletons and contigs using TIGR assembler http://nbc11.biolo gie.uni-kl.de/framed/Left/menu/auto/rightigr assembler and were termed as unigenes. The unigene sequences were blasted for homology search using BLASTX programme (default) at NCBI database, and categorised into the proteins with known function, the proteins with unknown function and the proteins with no match in the database. The unigenes were then grouped into functional categories using MIPS (Munich Information for Protein Sequences) function catalogue http://mips.gsf.de/ projects/function developed based on the information available on the function of a protein in Arabidopsis thaliana protein database. For this, the unigenes were individually assigned a unique locus name after the BLAST against the $A$. thaliana protein database. The locus names were fed to the MIPS functional catalogue and the genes were clustered under different functional categories.

\section{Expression validation by Northern and real time PCR (qRT-PCR)}

Slot blot Northern analysis was done for select EST clones of the forward SSH cDNA library to confirm if the ESTs population in the library indeed represented the genes overexpressed due to salt stress. It was also done to validate the EST redundancy in a functional category. For this, total RNA was isolated from the leaves of the control and $\mathrm{NaCl}$-treated S. maritima as described above and $10 \mu \mathrm{g}$ RNA per slot was vacuum blotted on to nylon membrane ( $\mathrm{N}^{+}$Hybond, Amersham). The blots were air-dried and UV cross-linked at $150 \mathrm{~mJ}$ using a UV cross linker (GS Gene linker, Bio-Rad). These were hybridized with the probe made by random primer $\alpha^{32}$ P-dATP labelling of the ESTs of interest. The PCR amplified actin fragment was radiolabelled similarly. This was hybridized with a RNA blot each of a control and a $\mathrm{NaCl}$ treated sample for the normalization of the RNA loading in the two cases. The hybridization and washing conditions were as described above [41].

In order to verify further the salt-induced expression or enhanced expression of the unigenes, real-time RT-PCR (qRT-PCR) was conducted for five of them encoding jasmonic acid induced protein, JAIP (FC932662), catalase (FC932734), phosphoethanolamine N-methyltransferase, PEAMT (FC932718), $\Delta^{1}$-pyrroline-5-carboxylate synthetase, P5CS(FC932725) and DnaJ (FC932656). The selected unigenes varied greatly in EST redundancy. qRTPCR was also performed to check the influence of $\mathrm{NaCl}$ on the expression of the gene encoding betainealdehyde dehydrogenase (BADH), the ultimate gene in the pathway of glycinebetaine synthesis from choline in plant. The gene encoding actin was amplified simultaneously for each set of qRT-PCR reaction for comparison and normalization of the data. RNA was isolated as and when required from the leaves of the control and $\mathrm{NaCl}$ treated plants as described above and treated with DNase to remove any DNA contamination. The quality and quantity of the RNA in each preparation was checked spectrophotometrically using NanoPhotometer (Implen, $\mathrm{GmbH}$ ). The qRT-PCR reaction was conducted using QuantiFast SYBR Green RT-PCR kit (Qiagen, USA) and Opticon-2 qRT-PCR machine (MJ Research, Bio-Rad). Each RT-PCR reaction mixture was prepared as per the instructions in the kit taking 100 ng of RNA and $1 \mu \mathrm{M}$ gene-specific primer in a final volume of $25 \mu \mathrm{l}$. The primers for all the genes, except $B A D H$, were designed based on the nucleotide sequence information of their ESTs. For designing the primer for $B A D H$, the nucleotide sequence information of its full-length cDNA clone from Suaeda salsa [DQ641924] was considered. The primers were obtained from Gene Link (NY, USA). The primer sequences for the various genes were: JAIP-For5'CAATCAAAGCTCCCTTTTCG, Rev5'AAGCCCGAAAACTCCAC TCT; Cat-For5'GAGTGGTTGATGCCCTGTCT, Rev5' TCTCATCTCGATCCCCAAAG; PEAMT-For5'TTGCCCTTGAG CGTTCTATT, Rev5'TACCTCCTGGCTTCAACCAT; P5 CSFor5'GATGTTTTTGCTGCCATTGA, Rev5' GC TAATC CC AACCTCAGCAC; DnaJ-For5'GGAATACAGGAGGGG GA CAT, Rev5'CCTTTTGGGAGAACCAAACA; BADH-For5' TGGAAAATTGCTCCAGCTCT, Rev5'CTGGACCTAATCCC GTCAAA; Actin-For5'AAACCACAAGCCCCTAAACC, Rev5 'TTGCATCACTCAGCACCTTC. The PCR reaction conditions were also set as per the instruction manual in the kit. After the completion of the reactions, threshold cycle $\left(C_{T}\right)$ value for each reaction was obtained with the help of the software attached with the machine and the difference in the transcript level (in fold) between the control and $\mathrm{NaCl}$ treated sample was calculated using Pfaffl method [42] considering the $C_{T}$ value of actin as the internal control. The fold change in the transcript levels of each gene (considered for qRT-PCR) upon $\mathrm{NaCl}$ treatment was presented as the mean \pm standard deviation (sd) of three independent experimental analysis.

\section{Enzyme activity study}

The effect of $\mathrm{NaCl}$ on the activity of two enzymes $\Delta^{1}$-pyrroline-5-carboxylate synthetase (P5CS, EC 1.5.1.12) and catalase (Cat, EC 1.11.1.6) was studied. The leaves of the control and $\mathrm{NaCl}$ treated plants were homogenized separately in chilled enzyme extraction buffer $(100 \mathrm{mM}$ Tris$\mathrm{HCl}$, pH 7.8 containing $10 \mathrm{mM} \mathrm{MgCl}_{2}, 1 \mathrm{mM}$ PMSF, 0.1 mM EDTA, 2\% PVPP, $1 \%$ protease inhibitor cocktail and $10 \mathrm{mM}$ DTT) in a cold room using pre-chilled mortar and pestles $[20,43]$. The homogenates were centrifuged twice 
at $4^{\circ} \mathrm{C}$ for $20 \mathrm{~min}$ at $20000 \times \mathrm{g}$. The protein in the supernatants was quantified by coomassie brilliant blue-dye binding method [44].

P5CS activity in the enzyme extract was determined as $\gamma$ glutamyl kinase by monitoring the formation of $\gamma$ glutamyl hydroxamate [45]. The enzyme mixture in a final volume of $0.5 \mathrm{ml}$ contained $50 \mathrm{mM}$ Tris- $\mathrm{HCl}(\mathrm{pH}$ 7.0), $50 \mathrm{mM}$ L-glutamate, $20 \mathrm{mM} \mathrm{MgCl}_{2}, 100 \mathrm{mM}$ hydroxamate-HCl, $10 \mathrm{mM}$ ATP and $50 \mu \mathrm{l}$ enzyme extract. After addition of the enzyme extract, the reaction mixture was incubated at $37^{\circ} \mathrm{C}$ for $15 \mathrm{~min}$. The reaction was stopped by adding $1 \mathrm{ml}$ of the stop buffer $\left(2.5 \mathrm{~g} \mathrm{FeCl}_{3}\right.$ and $6 \mathrm{~g}$ trichloroacetic acid in a final volume of $100 \mathrm{ml}$ of 2.5 $\mathrm{M} \mathrm{HCl}$ ). The precipitated proteins were removed by centrifugation, and the absorbance of the clear supernatant was read at $535 \mathrm{~nm}$ against a blank identical to the above but lacking ATP. The activity was expressed as the unit (U) $\mathrm{mg}^{-1}$ protein; $1 \mathrm{U}$ represented the amount of the enzyme (protein) required to produce $1 \mu \mathrm{mol}$ of $\gamma$-glutamyl hydroxamate (molar extinction co-efficient- $250 \mathrm{M}^{-1} \mathrm{~cm}^{-1}$ ) in one $\min$. The data presented are the means of at least three independent analyses.

The activity of catalase in the supernatant was measured following the method of Chance and Maehly [46] with some modification. The reaction mixture for catalase contained $25 \mathrm{mM}$ potassium phosphate buffer ( $\mathrm{pH}$ 6.8), 20 $\mathrm{mM} \mathrm{H} \mathrm{H}_{2} \mathrm{O}_{2}$ and the enzyme extract. The reaction was started by adding the enzyme extract. The decomposition of $\mathrm{H}_{2} \mathrm{O}_{2}$ was followed at $240 \mathrm{~nm}$, and was quantified using a standard graph prepared for $\mathrm{H}_{2} \mathrm{O}_{2}$ concentration. The activity was expressed as $\mathrm{U} \mathrm{mg}^{-1}$ protein, where $1 \mathrm{U}$ is the amount of the enzyme (protein) required to decompose $1 \mu \mathrm{mol}$ of $\mathrm{H}_{2} \mathrm{O}_{2}$ in $1 \mathrm{~min}$. The data presented are the means of at least three independent analyses.

The significance of difference in the enzyme activity between the samples was checked by Duncan's multiple range test for unequal sample size [47].

\section{In-gel catalase activity study}

The effect of $\mathrm{NaCl}$ on the activity of catalase was also studied by in-gel activity staining of the enzyme activity. The enzyme extracts from the leaves of the control and $\mathrm{NaCl}$ treated plants were obtained as above. The homogenizing buffer contained $10 \%$ glycerol in addition to the other ingredients [48]. The individual supernatant was mixed with $3 \times$ loading buffer (190 mM Tris $\mathrm{HCl}, \mathrm{pH} 6.8,20 \%$ glycerol, $65 \mathrm{mM}$ DTT, $0.002 \%$ bromophenol blue) in 2:1 ratio and loaded on to a native gel ( $7.5 \%$ separating and $4 \%$ stacking) supported by $10 \%$ glycerol [48]. Equal amount of protein $(40 \mu \mathrm{g})$ was loaded in each lane and the electrophoresis was conducted in a cold room by applying $10 \mathrm{~mA}$ current for the stacking gel and $20 \mathrm{~mA}$ for the separating gel. The electrophoresis was allowed to continue for $2 \mathrm{~h}$ after the dye crossed the separating gel. The gel was removed, soaked in $3.27 \mathrm{mM} \mathrm{H}_{2} \mathrm{O}_{2}$ for 25 min, rinsed quickly with distilled water and stained with solution containing $1 \%(\mathrm{w} / \mathrm{v})$ potassium ferricyanide and $1 \%(\mathrm{w} / \mathrm{v})$ ferric chloride. The presence of catalase was visualized as negative band. The progress of staining was stopped by removing the staining solution and adding $1 \%$ $\mathrm{HCl}$.

\section{Results}

\section{SSH library construction and their differential screening}

The agarose plating of the competent E. coli cells transformed for the ESTs from the forward and the reverse SSH cDNA libraries yielded several transformed colonies. From the four plating done for each SSH cDNA library, 492 recombinant colonies for the forward and 502 colonies for the reverse library could be picked-up. The results of the differential screening of the EST clones from both the forward and the reverse SSH cDNA libraries are shown in Fig. 1. Most of the 150 spotted plasmids from the randomly picked transformed colonies generated for the forward subtracted SSH cDNA showed hybridization signal with the probe made from the secondary PCR product of the forward subtracted SSH cDNA (Fig. 1a). The intensity of the spots varied greatly suggesting the presence of variable number of transcript messages of the individual overexpressing genes. Upon hybridization of the duplicate blot with the probe made from the secondary PCR product of the reverse subtracted SSH cDNA, only a few hybridization signals were observed (Fig. 1b). This suggested that the transcript messages present in the forward $\mathrm{SSH}$ cDNA library were different from that present in the reverse SSH cDNA library, and that the library represented mostly the salt-induced transcript messages. A few hybridization signals obtained could be an artefact or the subtraction of the cDNAs of a few overexpressing genes might not have been total during the preparation of the reverse SSH cDNA library.

For the screening of the reverse SSH cDNA library, 96 plasmid DNA samples, isolated from the randomly picked transformed bacterial colonies obtained for the reverse subtracted SSH cDNA, were blotted and hybridized with the probe made from the secondary PCR product of either the reverse or the forward subtracted SSH cDNA. As expected, most of the 96 spots gave hybridization signal with the probe made from the secondary product of the reverse subtracted SSH cDNA (Fig. 1d), but only a few hybridization signals were observed with the probe made from the secondary PCR product of the forward subtracted SSH cDNA (Fig. 1c). This suggested that the removal of the salt-induced or -unaffected messages during the subtraction step was more or less complete while constructing the reverse SSH cDNA library, and that the library represented mostly the messages that were down regulated due to the salt stress. 

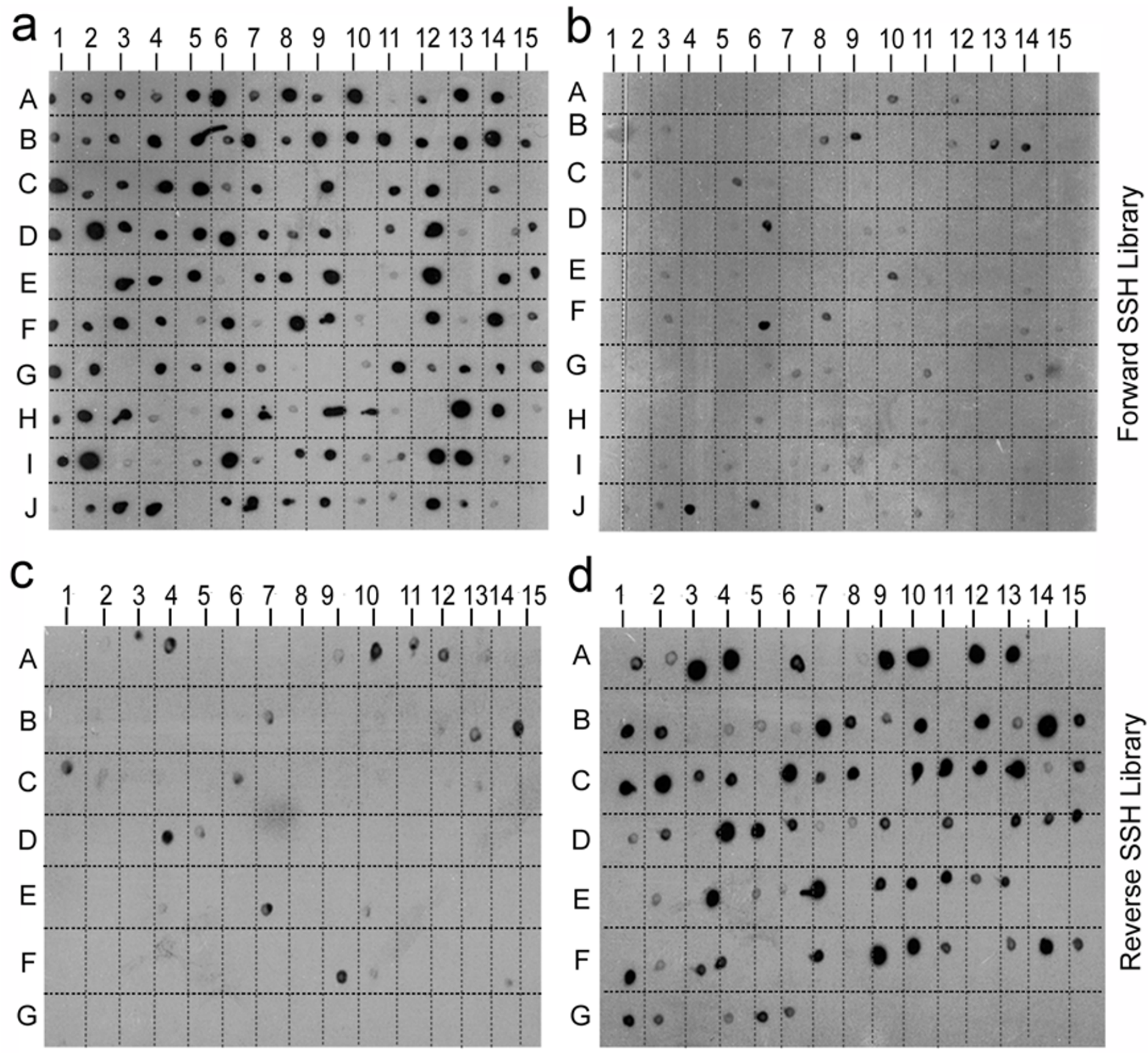

Forward SSH Library Probe

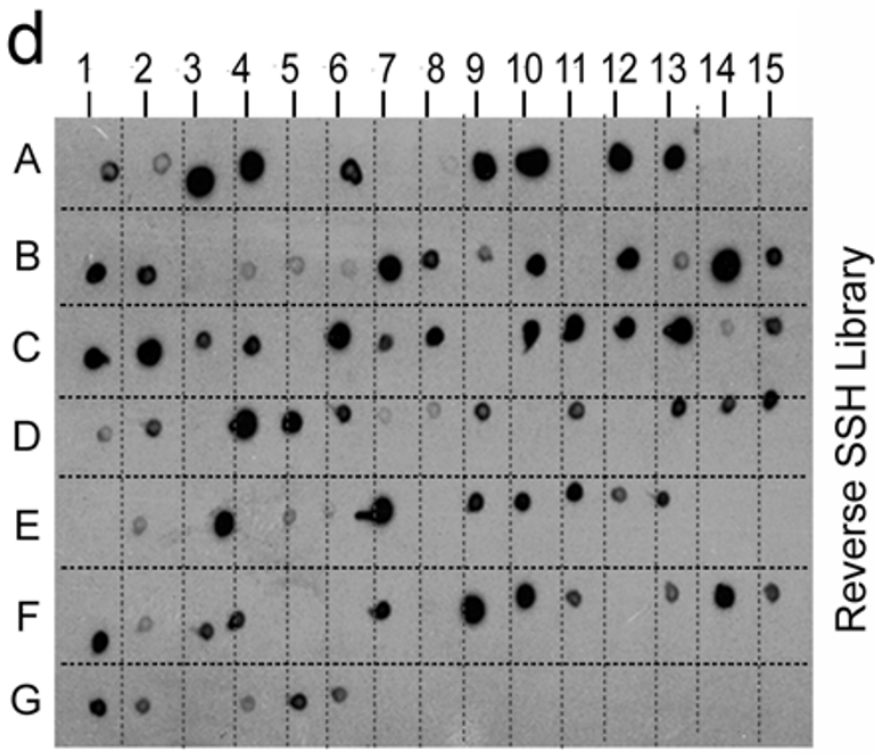

Reverse SSH Library Probe

\section{Figure I}

Results of differential screening of the clones from forward and reverse SSH cDNA libraries. Young S. maritima plants were exposed to $425 \mathrm{mM} \mathrm{NaCl}$ for $24 \mathrm{~h}$ (treated). The plants of the same age not receiving $\mathrm{NaCl}$ treatment served as control. Plates $a$ and $b$ : the membranes were blotted with clones from the forward SSH cDNA library. Plates c and d: the membranes were blotted with the clones from the reverse SSH cDNA library. Plates a and c: the blotted membranes were screened by the probe made from the forward subtracted SSH cDNA. Plates b and d: the blotted membranes were screened by the probe made from the reverse subtracted SSH cDNA.

Sequencing of the forward subtracted SSH cDNA, contig assembly and annotation

The cloned ESTs of only the forward SSH cDNA library were considered for sequencing. This is because these represented the genes overexpressing in response to the $\mathrm{NaCl}$ treatment, and hence could be more relevant from the point of view of salt tolerance than the genes down-regulated by the $\mathrm{NaCl}$ treatment, represented by the reverse SSH cDNA library. Only 429 clones were found to be good for annotation and contig assembly (Table 1). These ESTs could be grouped into 89 singletons and 78 contigs represented by 340 ESTs with an overall EST redundancy 
of $81.8 \%$ (Table 1). Thus, the forward SSH cDNA library represented 167 unigenes (the combined set of contigs and singletons), which either overexpressed in response to the $\mathrm{NaCl}$ treatment or expressed only after the $\mathrm{NaCl}$ treatment. More than half of the ESTs from the forward SSH cDNA library could be assigned putative function on the basis of the sequence similarity to the genes or proteins of known function in the GenBank (see Additional file 1). The maximum similarity of the ESTs to a given protein in the database in terms of BLASTX $\mathrm{E}$ value is also given in the table. More than $30 \%$ of the unigenes showed no match in the protein database, and approximately $4 \%$ of the sequences represented proteins whose function is not known (see Additional file 1). Most of the unigenes, which represented known proteins showed BLASTX E value $<10^{-2}$. Only 15 unigenes finding matches in the protein database showed BLASTX homology at E $>10^{-2}$, and of these nine were either hypothetical/unknown proteins or proteins with putative function. Hence, these may be considered as the unigenes with no match in the database. All the EST sequences are available at NCBI [GenBank: FC932656-FC932657, FC932659-FC932666, FC932668 -FC932807 and FG228208-FG228224]

Among the unigenes identified, that reported to be induced by jasmonic acid showed the highest expression; the EST redundancy of this particular gene was found to be as high as $7.69 \%$ (Table 2) out of the total contig EST redundancy of $81.8 \%$ (Table 1). In fact, two isoforms of the gene encoding jasmonic acid-induced protein (JAIP) were found to be overexpressing in the test plant upon $\mathrm{NaCl}$ treatment, one with EST redundancy of $2.80 \%$ and the other with EST redundancy of 7.69\%. Down the line, the next gene showing high EST redundancy was that

Table I: ESTs summary of the forward SSH cDNA library of S. maritima.

\begin{tabular}{ll}
\hline Descriptive category & Values \\
\hline No. of high quality ESTs & 429 \\
Mean EST length (bp) & 392 \\
EST size range (bp) & $74-814$ \\
No. of singletons & 89 \\
No. of contiguous sequences (contigs) & 78 \\
No. of unigenes & 167 \\
No. of ESTs in contigs & 340 \\
Contig EST redundancy (\%) & 81.8 \\
Maximum EST redundancy in a contig (\%) & 7.7
\end{tabular}

Forward SSH cDNA library, representing the salt-induced genes, was constructed considering the mRNA isolated from the leaves of the $\mathrm{NaCl}$-treated $(24 \mathrm{~h})$ plant as 'Tester' and that from the leaves of the control plant as 'Driver'. The cDNAs of the library were cloned and transformed and 502 ESTs from such clones were sequenced. The results are summarized.

aPercentage of the faction of ESTs assembled in the contigs/total no. of ESTs.

bPercentage of the fraction of ESTs in a contig/total no. of ESTs encoding homeodomain leucine zipper transcription factors, ATB-1 (Homeobox leucine zipper) and HDZ3 (Homeodomain leucine zipper), each showing EST redundancy of $3.76 \%$. The transcription factor EREBP (Ethylene responsive element binding protein) and a putative zinc binding protein with RING domain (Zn-finger protein, $\mathrm{ZnF}$ ) were among the protein products of highly overexpressing (NaCl-induced) genes after $A T B-1$ and HDZ3 showing EST redundancy of 0.89 and $1.17 \%$, respectively. In addition, there was overexpression of genes of two other transcription factors, $\mathrm{C} 2 \mathrm{H} 2$ zinc finger (C2H2-ZnF) family protein and white collar (WC1) protein, and also of a protein, pasticcino-1 (PAS1) involved in regulation of the NAC transcription factors. The EST redundancy of these genes were, however, very low.

Besides that of transcription factors, the expression of genes encoding several other proteins with regulatory function was also found to be enhanced in the plant in response to the $\mathrm{NaCl}$ treatment (Table 2). One group among them consisted of the genes encoding proteins with various recognized domains, such as CBS, F-box and $\mathrm{C} 2$, and motifs such as $\mathrm{C} 3 \mathrm{H} 4$ zinc finger and leucine rich repeat, mediating protein-protein interaction in various biochemical events such as polyubiquitination, transcription elongation, centromeric binding, translational elongation, membrane trafficking, etc. The second group was comprised of the genes of G protein (Transducin, GTP binding protein) and AMP-binding (Adenosine monophosphate binding) protein, which are involved in signal perception and transduction. The genes of other proteins with some possible regulatory role that overexpressed in response to the $\mathrm{NaCl}$ treatment was O-linked GlcNAc (Nacetylglucosamine) transferase (OGT) regulating protein function by $\mathrm{O}$-linked $\beta$ - $\mathrm{N}$-acetylglucosamine addition on the serine/threonine residue, and DnaJ like protein functioning as co-chaperones helping in protein translation, translocation, folding, assembly and deassembly. Besides, the expression of the genes encoding proteins constituting the protein synthesis machinery itself, like preRNA splicing factor, sigma like transcription factor, $60 \mathrm{~S}$ ribosomal P0 protein, appr-1p (ADP-ribose 1"-phosphate) processing enzyme family protein, eukaryotic elongation factor $1 \mathrm{~A}$ and valyl tRNA synthetase involved in transcription, mRNA and tRNA processing and translation was greatly increased in response to the salt treatment. The most significant enhancement in the expression among them was of the gene encoding $60 \mathrm{~S}$ acidic ribosomal P0 showing EST redundancy of $0.93 \%$.

A clear distinguishing feature of differential gene expression in the test plant in response to the $\mathrm{NaCl}$ treatment was the overexpression of the genes encoding proteins performing various physiological functions related to adaptation of plants to saline and/or drought conditions 
Table 2: Unigene sequences (ESTs) representing proteins with regulatory roles.

\begin{tabular}{|c|c|c|c|c|}
\hline $\begin{array}{l}\text { EST accession number } \\
\text { (GenBank) }\end{array}$ & $\begin{array}{l}\text { Name of the proteins/ } \\
\text { genes }\end{array}$ & $\begin{array}{l}\text { EST redun-dancy for a } \\
\text { gene }(\%)^{\mathrm{a}}\end{array}$ & BLASTX search E-value & Mean EST length (bp) \\
\hline FC932788 & $\begin{array}{l}60 \mathrm{~S} \text { acidic ribosomal } \\
\text { protein PO }\end{array}$ & 0.93 & $4.00 \mathrm{E}-46$ & 657 \\
\hline FG228222 & $\begin{array}{l}\text { Adenosine monophosphate } \\
\text { binding protein-5 } \\
\text { (AMP-binding) }\end{array}$ & 0.23 & $1.00 \mathrm{E}-64$ & 543 \\
\hline FC932702 & $\begin{array}{l}\text { Appr-I-p processing } \\
\text { enzyme family protein }\end{array}$ & 1.40 & $8.00 \mathrm{E}-12$ & 132 \\
\hline FC932664 & $\begin{array}{l}\text { ATHB-I } \\
\text { (Homeobox-leucine zipper } \\
\text { protein) }\end{array}$ & 3.76 & $4.00 \mathrm{E}-18$ & 373 \\
\hline FC932731 & $\begin{array}{l}\text { C2 domain-containing } \\
\text { protein }\end{array}$ & 0.23 & $3.00 \mathrm{E}-14$ & 601 \\
\hline FC932705 & $\begin{array}{l}\mathrm{C} 2 \mathrm{H} 2 \text { type zinc finger family } \\
\text { protein }\end{array}$ & 0.23 & $3.00 \mathrm{E}-09$ & 326 \\
\hline FC932694 & $\begin{array}{l}\text { C3H4-type zinc finger } \\
\text { (RING finger) protein }\end{array}$ & 0.23 & $2.00 \mathrm{E}-12$ & 247 \\
\hline FC932783 & $\begin{array}{l}\text { CBS domain-containing } \\
\text { protein }\end{array}$ & 0.23 & $2.00 \mathrm{E}-25$ & 254 \\
\hline FC932656 & Dnal protein, putative & 0.47 & $4.00 E-67$ & 467 \\
\hline FC932677 & $\begin{array}{l}\text { Ethylene responsive } \\
\text { element binding protein } \\
\text { (EREBP) }\end{array}$ & 0.93 & $6.00 \mathrm{E}-16$ & 160 \\
\hline FG228218 & $\begin{array}{l}\text { Eukaryotic elongation factor } \\
\text { IA }\end{array}$ & 0.23 & $3.00 \mathrm{E}-42$ & 321 \\
\hline FC932688 & $\begin{array}{l}\text { F-box domain containing } \\
\text { protein, putative }\end{array}$ & 0.23 & 0.056 & 509 \\
\hline$\underline{F C 932771}$ & $\begin{array}{l}\text { GTP-binding protein, } \\
\text { putative }\end{array}$ & 0.23 & $8.00 \mathrm{E}-44$ & 276 \\
\hline$\underline{\mathrm{FC} 932675}$ & $\begin{array}{l}\text { Homeodomain leucine } \\
\text { zipper protein HDZ3 }\end{array}$ & 3.76 & $2.00 \mathrm{E}-18$ & 373 \\
\hline FC932662 & $\begin{array}{l}\text { Jasmonate-induced protein } \\
\text { homolog }\end{array}$ & 7.69 & 0.001 & 386 \\
\hline FC932679 & $\begin{array}{l}\text { Jasmonate-induced protein } \\
\text { homolog }\end{array}$ & 2.80 & I.00E-05 & 520 \\
\hline$\underline{F C 932804}$ & $\begin{array}{l}\text { Leucine-rich repeat family } \\
\text { protein }\end{array}$ & 0.23 & $9.00 \mathrm{E}-28$ & 315 \\
\hline FC932737 & $\begin{array}{l}\text { O-linked GlcNAc } \\
\text { transferase like }\end{array}$ & 0.93 & $1.00 \mathrm{E}-04$ & 307 \\
\hline FC932759 & Pasticcino I & 0.23 & $1.00 \mathrm{E}-62$ & 626 \\
\hline FC932684 & $\begin{array}{l}\text { Pre-mRNA splicing factor } \\
\text { ATP-dependent RNA } \\
\text { helicase-like protein }\end{array}$ & 0.23 & 2.30 & 610 \\
\hline$\underline{\text { FC932706 }}$ & $\begin{array}{l}\text { Putative sigma-like } \\
\text { transcription factor }\end{array}$ & 0.23 & $2.00 \mathrm{E}-09$ & 271 \\
\hline FC932765 & $\begin{array}{l}\text { Putative Zn-binding protein } \\
\text { with RING finger }\end{array}$ & 1.17 & $7.00 \mathrm{E}-22$ & 457 \\
\hline FG228209 & Transducin family protein & 0.23 & I.00E-47 & 380 \\
\hline FG228219 & $\begin{array}{l}\text { Valyl-tRNA synthetase, } \\
\text { putative }\end{array}$ & 0.23 & $6.00 \mathrm{E}-36$ & 539 \\
\hline FC932666 & $\begin{array}{l}\text { White collar I protein } \\
\text { (WCI) }\end{array}$ & 0.23 & 9.70 & 311 \\
\hline
\end{tabular}

ESTs sequences from the forward SSH cDNA library of S. maritima were grouped into singletons and contigs using TIGR Assembler and were termed as unigenes. The unigene sequences were blasted for homology search using BLASTX programme (default) at NCBI database. The search results for those unigenes representing proteins having regulatory function are summarized. EST redundancy of each unigene is also given along with the average size of the ESTs constituting the unigene.

aPercentage of the fraction of ESTs representing a unigene/total no. of ESTs

bGenes reported to be induced by salt 
(Table 3). At least three of these gene products function in association with the cellular membranes. The NaClinduced expression of the gene encoding one among them, the choline transporter, was the maximum in the group; two isoforms were found to be expressing with a combined EST redundancy of $2.82 \%$. The second gene encoding the membrane associated protein with high EST redundancy was the cation-efflux transporter; overexpression of two isoforms of the gene was observed in this case as well. A putative $\mathrm{Na}^{+} / \mathrm{H}^{+}$antiporter was the third gene that was found to be overexpressed under $\mathrm{NaCl}$ stress, although the BLASTX sequence homology for the gene product was very less $(E=7.6)$. Besides the genes encoding membrane proteins, the genes for the enzymes possibly playing important role in cell wall formation, for example xyloglucan endotransglycosylase (2 isoforms) and expansin-3, also showed overexpression with high EST redundancy.

Overexpression of the genes known to be directly or indirectly related to a well established physiological adaptation process in plants to salt or drought stress, the osmotic adjustment, was prominently reflected in the test plant in response to the $\mathrm{NaCl}$ treatment (Table 3 ). The most overexpressing gene in this category was that encoding phosphoethanolamine N-methyltransferase (PEAMT) related to the synthesis and accumulation of glycinebetaine, a well known compatible solute for osmotic adjustment in plants under salt and drought stresses. The enzyme catalyzes the conversion of phosphoethanolamine (P-EA) to phosphocholine, a precursor of choline and glycinebetaine (Fig. 2). Three isoforms of PEAMT were detected with a combined EST redundancy of $1.63 \%$. Besides, the expression of the gene encoding methionineadenosyl transferase (S-adenosyl-L-methionine synthetase, SAMS), the enzyme responsible for the synthesis of S-adenosylmethione (SAM) required for the conversion of ethanolamine (EA) to P-EA by methylation (Fig. 2), also increased greatly showing EST redundancy of $0.93 \%$. During the transmethylation reaction, SAM is converted to Sadenosyl-L-homocysteine (SAH), which is inhibitory to all SAM dependent methyltransferases, and hence it should be metabolized and recycled, which is done by SAH hydrolase, SAHH (Fig. 2). The expression of SAHH

Table 3: The Unigene sequences (ESTs) representing proteins important for the salt adaptive phsiological processes.

\begin{tabular}{|c|c|c|c|c|}
\hline $\begin{array}{l}\text { EST accession number } \\
\text { (GenBank) }\end{array}$ & $\begin{array}{l}\text { Name of the proteins/ } \\
\text { genes }\end{array}$ & $\begin{array}{l}\text { EST redun-dancy for a } \\
\text { gene }(\%)^{\mathrm{a}}\end{array}$ & BLASTX search E-value & Mean EST length (bp) \\
\hline FC932725 & $\begin{array}{l}\Delta^{\prime} \text {-pyrroline-5-carboxylate } \\
\text { synthetase }^{b}\end{array}$ & 0.23 & $5.00 \mathrm{E}-36$ & 227 \\
\hline FC932672 & Carbonic anhydrase ${ }^{b}$ & 0.70 & $2.00 \mathrm{E}-73$ & 606 \\
\hline FC932674 & Carbonic anhydrase ${ }^{b}$ & 0.70 & $5.00 \mathrm{E}-73$ & 574 \\
\hline FC932784 & Cation-efflux transporter & 0.93 & $9.00 \mathrm{E}-66$ & 686 \\
\hline FG22821I & Cation-efflux transporter & 0.23 & $5.00 \mathrm{E}-64$ & 581 \\
\hline FC932758 & CCL (CCR-LIKE) protein & 0.93 & 0.24 & 152 \\
\hline FC932738 & $\begin{array}{l}\text { Choline transporter- } \\
\text { related }\end{array}$ & 0.93 & $3.00 \mathrm{E}-14$ & 295 \\
\hline FC932763 & $\begin{array}{l}\text { Choline transporter- } \\
\text { related }^{b}\end{array}$ & 1.89 & $1.00 \mathrm{E}-16$ & 305 \\
\hline$\underline{F C 932670}$ & Expansin 3 & 0.47 & $3.00 \mathrm{E}-23$ & 727 \\
\hline FC932700 & $\begin{array}{l}\text { Methionine } \\
\text { adenosyltransferase }\end{array}$ & 0.93 & $2.00 \mathrm{E}-74$ & 407 \\
\hline FC932718 & $\begin{array}{l}\text { Phosphoethanolamine N- } \\
\text { methyltransferase }^{\mathrm{b}}\end{array}$ & 0.70 & $8.00 \mathrm{E}-124$ & 814 \\
\hline$\underline{F C 932801}$ & $\begin{array}{l}\text { Phosphoethanolamine N- } \\
\text { methyltransferase }\end{array}$ & 0.70 & $1.00 \mathrm{E}-\mathrm{I} 40$ & 803 \\
\hline$\underline{F G 228215}$ & $\begin{array}{l}\text { Phosphoethanolamine N- } \\
\text { methyltransferase }^{b}\end{array}$ & 0.23 & $2.00 \mathrm{E}-66$ & 804 \\
\hline FC932680 & $\begin{array}{l}\text { Putative } \mathrm{Na}(+) / H(+) \text { anti- } \\
\text { porter }\end{array}$ & 0.47 & 7.6 & 225 \\
\hline$\underline{F C 932696}$ & $\begin{array}{l}\text { S-adenosyl-L-homocystein } \\
\text { hydrolase }\end{array}$ & 0.23 & $2.00 \mathrm{E}-74$ & 486 \\
\hline$\underline{F C 932721}$ & $\begin{array}{l}\text { Xyloglucan } \\
\text { endotransglycosylase I }\end{array}$ & 0.70 & I.00E-3। & $44 I$ \\
\hline FC932774 & $\begin{array}{l}\text { Xyloglucan } \\
\text { endotransglycosylase I }\end{array}$ & 0.70 & $5.00 \mathrm{E}-30$ & 439 \\
\hline
\end{tabular}

BLASTX results for those unigenes representing proteins performing various physiological functions related to adaptation of plants to saline condition and possibly vital for the salt adaptive physiological processes. Other details as in Table 2.

aPercentage of the fraction of ESTs representing a unigene/total no. of ESTs

bGenes reported to be induced by salt 


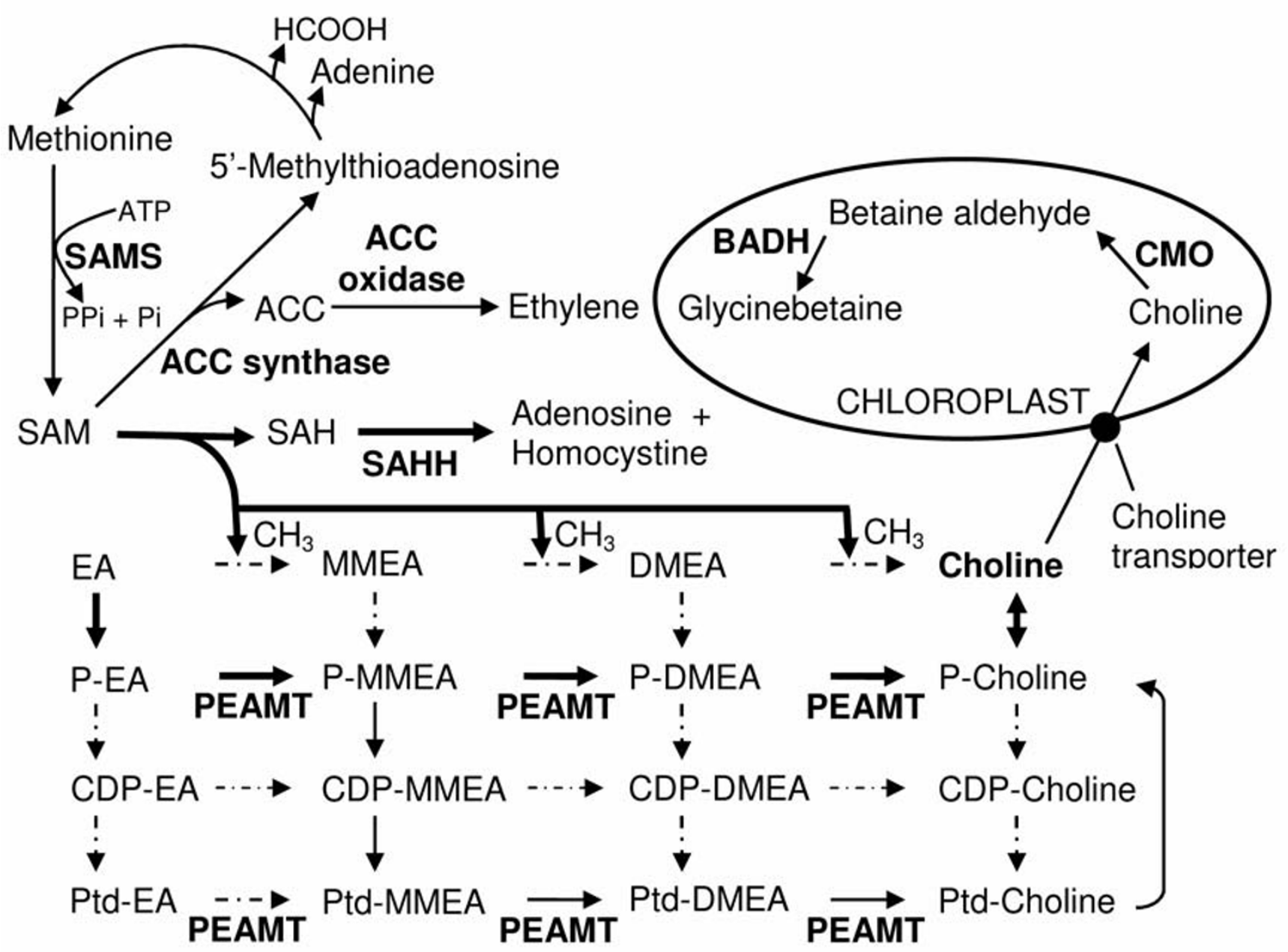

Figure 2

Biosynthetic pathways of glycinebetaine and ethylene in plant. Glycinebetaine in plant is synthesized from choline, which in turn is synthesized by three sequential $\mathrm{N}$-methylation of $\mathrm{NH}_{2}$-moiety of ethanolamine (EA), phospho-ethanolamine (P-EA) or phosphatidyl-ethanolamine (Ptd-EA) catalysed by phosphoethanolamine N-methyltransferase (PEAMT). Monomethylehthanolamine (MMEA), dimethylethanolamine (DMEA) and their phsopho- (P-), citidine diphosphate- (CDP-) and phosphatidyl- (Ptd-) derivatives are various intermediates. Methyl group is donated at each step by SAM (S-adnosylmethionine). SAM is also the methyl donor for ethylene synthesis catalysed by ACC synthase and ACC oxidase. The by-product SAH is broken down further by SAHH (S-adenosylhomocysteine hydrolase). SAM is regenerated from methionine by SAMS (S-adenosyl-Lmethionine synthase).

was also enhanced in the plant by the salt treatment. In addition to the overexpression of the genes encoding the enzymes involved in glycinebetaine synthesis, the study also revealed enhanced expression of the gene encoding $\Delta^{1}$-pyrroline-5-carboxylate synthetase (P5CS), an enzyme involved in the biosynthesis of proline, which is another well known osmoticum.

Among the other genes highly overexpressing and possibly having important role to play in the physiological processes leading to adaptation of a plant to abiotic stress were those encoding CCR (Cold-circadian rhythm-RNA binding)-like (CCL) protein and two isoforms of carbonic anhydrase (CA); while CCL expressed with an EST redundancy of $0.93 \%$, the two isoforms of $C A$ expressed with a combined EST redundancy of $1.40 \%$ (Table 3 ). The genes of the other known enzymes and proteins performing important metabolic functions, which were found to be overexpressed, although with low EST redundancy, are listed in the Supplementary table (see Additional file 1) 


\section{Northern blot and qRT-PCR analysis of representative ESTs}

To validate further that the EST population of the forward SSH cDNA library really represented the population of the genes that overexpressed or additionally expressed in the test plant upon the salt treatment, Northern blot analysis was performed for a few select cDNA clones that varied in EST redundancy (Fig. 3). Overexpression of all these genes under salt stress was visible. Hybridization signal for the gene encoding JAIP was not detected in the control plant, suggesting that the gene was expressed only upon exposure of the plant to $\mathrm{NaCl}$. Varying probe hybridization signal was observed for the genes encoding different proteins, and when the signals were normalized with the respective actin signal, the level of expression of the individual genes quite matched their EST abundance (or redundancy) in the forward SSH cDNA library. The qRTPCR data also revealed very high expression of the gene encoding JAIP (Fig. 4). Overexpression of P5CS in the $\mathrm{NaCl}$-treated plant was the least among the genes selected for qRT-PCR. This was also reflected in the slot-blot hybridization (Fig. 3). However, the qRT-PCR result showed a greater overexpression of DnaJ in the $\mathrm{NaCl}$ treated plant when compared to the result of the slot-blot hybridization. A slight overexpression of $B A D H$ was detected in the test plant upon $\mathrm{NaCl}$ treatment, although cloning and sequencing of the cDNAs from the forward subtracted SSH cDNA library did not show any presence of EST of the gene.

\section{Activity assay of catalase and P5CS}

The activity of catalase and P5CS was checked to validate the result of the forward subtractive hybridization at the physiological level. The genes of these two enzymes overexpressed with the least EST redundancy (Table 2). The activity of P5CS showed significant increase only at 425 $\mathrm{mM} \mathrm{NaCl}$ treatment (Fig. 5a). Catalase on the other hand showed significant increase in its activity in the plant at all the NaCl-treatment concentrations (Fig. 5b). The increase in the activity of the enzyme was, however, not NaCl-concentration dependent, as the increase was similar at all the treatment concentrations. The accelerating effect of $\mathrm{NaCl}$ on the activity of catalase is also visible from the in-gel assay of the enzyme activity performed for the plant exposed to $425 \mathrm{mM} \mathrm{NaCl}$ treatment concentration (Fig. 5c).

\section{Functional categorization of the unigenes}

The functional classification of the unigenes was carried out using MIPS (Munich Information Centre for Protein Sequences) functional catalogue http://mips.gsf.de/ projects/funcat, which is based on the pathways where the proteins act. These were classified into 19 functional subcategories (marked A-S, Fig. 6) excluding the unclassified (unknown and unnamed) proteins (marked T, Fig. 6), representing $4.3 \%$ of the unigenes, and the proteins for which no matches were found in the database (marked $U$, Fig. 6). The latter represented nearly one third (32.5\%) of the unigenes. Among the functional categories, the genes encoding proteins responsible for subcellular localization of biomolecules (sub-category $\mathrm{S}$ ) were found to be expressing the most making $14.1 \%$ contribution. The genes encoding protein with binding function or co-factor requirement (sub-category $\mathrm{G}$ ) followed the next with a contribution of $9.4 \%$. In fact, this sub-category is a constituent of a major functional category, the information pathways (Fig. 6, sub-categories C-H). This represented $18 \%$ of the total unigenes belonging to the various other sub-categories like cell cycle and DNA processing $(1.1 \%$, C), transcription $(1.8 \%, \mathrm{D})$, protein synthesis $(1.8 \%, \mathrm{E})$, protein fate $(3.2 \%, F)$ and protein activity regulation $(0.7 \%, \mathrm{H})$, in addition to the sub-category $\mathrm{G}$ (Fig. 6). The next highest representation was by the genes encoding proteins involved in metabolism (Fig. 6, sub-categories A and $\mathrm{B})$, contributing $11.6 \%$ of the total unigenes. The genes encoding proteins concerned with perception and response to stimuli (Fig. 6, represented by sub-categories $\mathrm{J}-\mathrm{M}$ ), such as those involved in cellular communication (J, $0.7 \%)$, cell rescue $(\mathrm{K}, 3.6 \%)$, interaction with the cellular environment ( $\mathrm{L}, 4.3 \%)$ and systemic interaction with the environment $(M, 2.2 \%)$ constituted $10.8 \%$ of the total unigenes. The representation by the genes encoding proteins taking part in developmental processes, such as cell fate (sub-category N, 1.4\%), systemic development (subcategory $\mathrm{O}, 1.8 \%$ ), biogenesis of cellular components (sub-category P, 2.2\%), cell type differentiation (sub-category $\mathrm{Q}, 0.4 \%$ ) and organ differentiation (sub-category R, $0.4 \%$ ) was found to be the least $(6.2 \%)$ in the total unigenes.

Representation of the ESTs in the information pathway (Fig. 7, sub-categories C-H) was the highest (47.1\%). The second highest EST representation $(18.8 \%)$ was for the proteins involved in developmental processes (Fig. 7, subcategories N-R), although the total unigene representation in this category was the least (6.2\%). The genes encoding proteins involved in perception and response to stimuli (Fig. 7, sub-categories J-M) also made a greater EST representation $(11.6 \%)$ than the representation made by the total unigenes $(8.6 \%)$ in the group. The relative overexpression of the genes encoding protein involved in subcellular localization (Fig. 7, sub-category S) was the least $(3.8 \%)$. While the percentage of EST representing the unclassified proteins (Fig. 7, sub-category $\mathrm{T}$ ) remained similar to that of the total unigene representation in the group, the EST representation for the proteins with no similarity in the database (Fig. 7, sub-category U) was found to be very less $(4.7 \%)$ compared to the representation made by the unigenes (32.5\%) in the group (Fig. 6). 


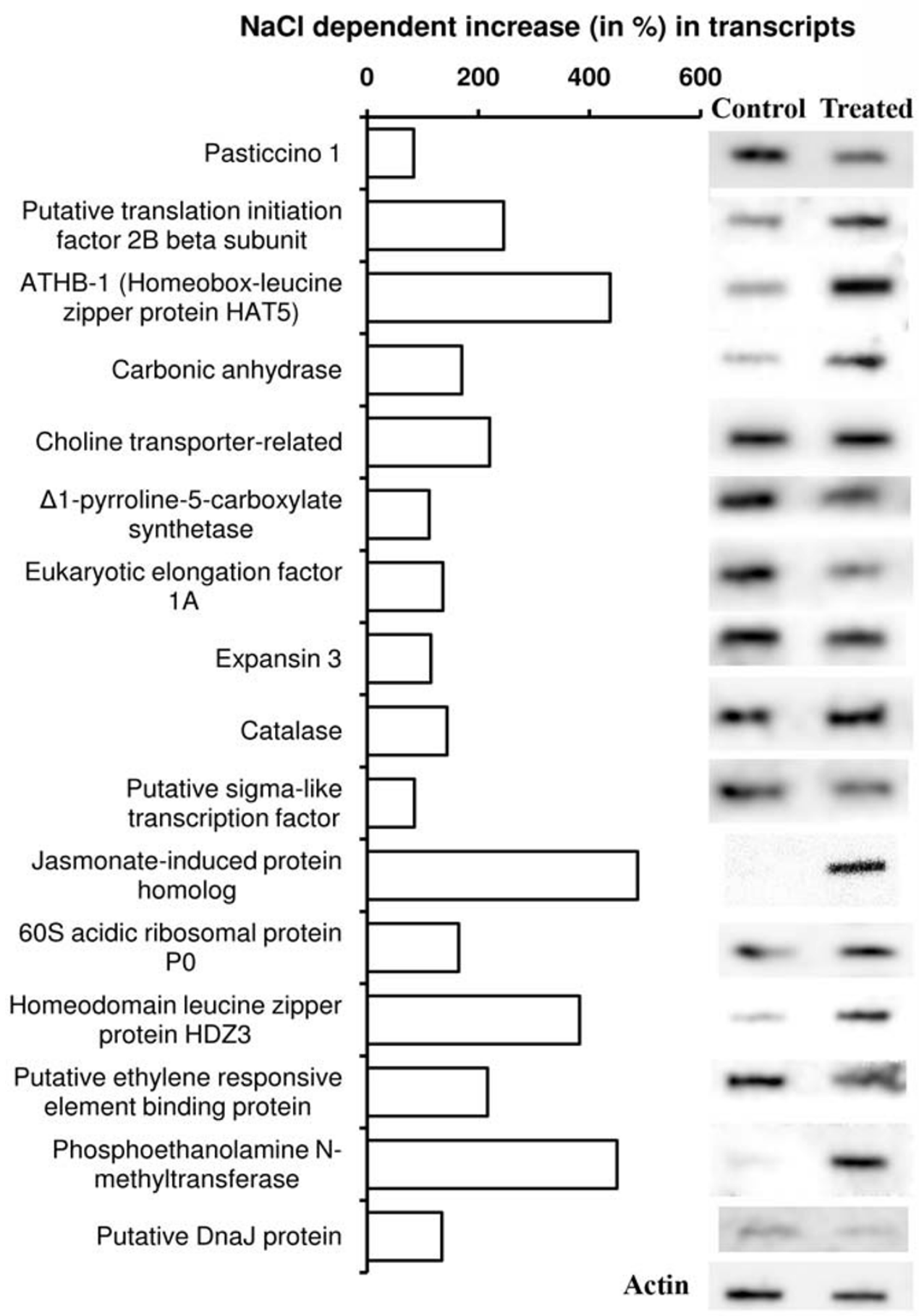

Figure 3

Northern analyses of a few select forward subtracted SSH cDNA clones. RNA isolated from the leaves of the control and $425 \mathrm{mM} \mathrm{NaCl}$-treated plants and blotted onto Hybond $\mathrm{N}^{+}$membrane was hybridized with the individual radiolabelled ESTs. A RNA blot each for the control and $\mathrm{NaCl}$-treated sample was hybridized with PCR amplified radiolabelled actin fragment. The horizontal bars against the individual genes represent increase (in\%) in transcripts of the respective genes in response to $\mathrm{NaCl}$ treatment of the plant when compared to control. The values were obtained after normalization of the blot intensities of actin for the control and $\mathrm{NaCl}$ treated sample. 


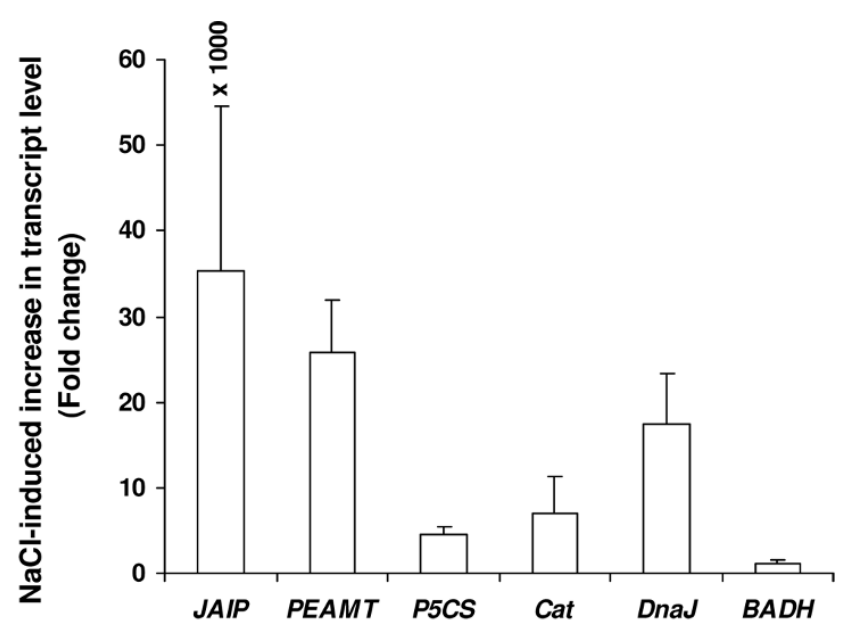

Figure 4 Expression study by Real-time RT-PCR of a few unigenes varying in EST redundancy. Real-time PCR ( $q R T$ PCR) was conducted for five unigenes encoding JAIP, catalase, PEAMT, P5CS and DnaJ to see the effect of $\mathrm{NaCl}$ treatment on their expression. qRT-PCR was also performed for $B A D H$. Actin gene served as the internal control. RNA isolated from the leaves of control and $\mathrm{NaCl}$ treated plants was individually set for qRT-PCR using QuantiFast SYBR Green RT-PCR kit (Qiagen, USA) and I $\mu$ M gene-specific primer. Each bar represents the number of fold increase in the transcript level of a gene in the plant upon $\mathrm{NaCl}$ treatment compared to the control level. The values presented are the mean \pm standard deviation (sd) of three independent experimental analysis.

\section{Discussion}

Over the last decade, vast insight into the plant growth and development and other plant processes have been gained because of the growth and development in molecular biology techniques. Suppression subtractive hybridization (SSH) is among such techniques being largely used to isolate the genes that are differentially expressed in contrasting environments. Although the PCR-based SSH technique has been used to know the genes differentially expressed in some plants under salt stress $[18,19,40,49]$, no report exists on the salt-responsive genes in natural halophyte, which is likely to give better information on the genes relevant to salt tolerance than the studies carried out on other plants. The present study has been an attempt in this direction. Although SSH is a powerful technique that enriches the differentially expressed genes, it is by no means perfect. This is also evident from the present study as the probe prepared using the reverse subtracted SSH CDNA showed hybridization with the forward subtracted SSH cDNA clones, or vice-versa (Fig. 1b, c), which was not expected. Northern blot analysis of select forward subtracted cDNA clones, including that showing hybridi-

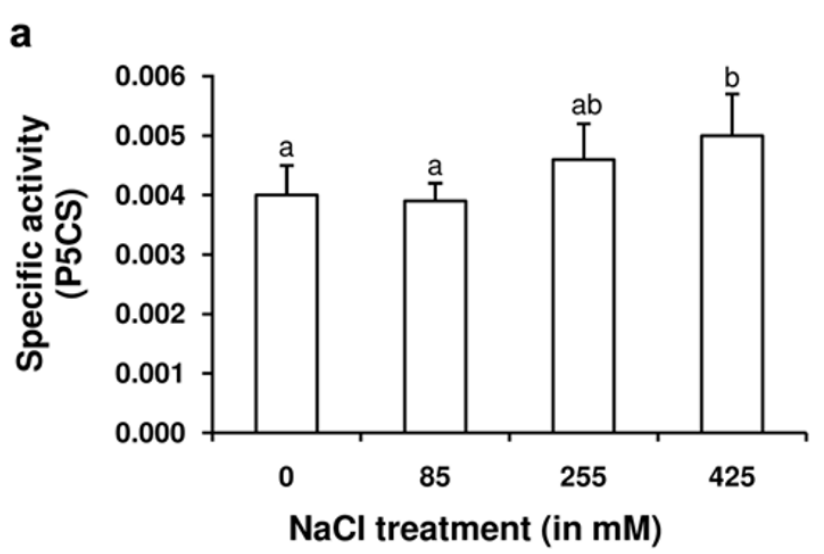

b

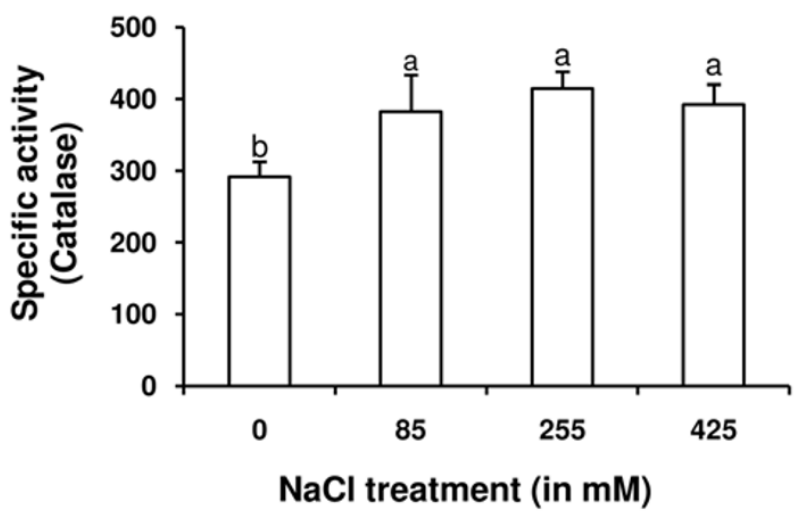

C

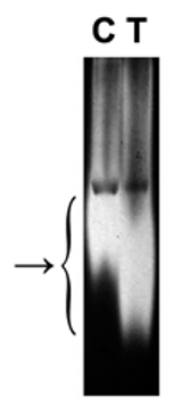

Figure 5

Activity study of $\Delta^{\prime}$-pyrroline-5-carboxylate synthetase (P5CS) and catalase. The enzyme extract from the leaves of control and $\mathrm{NaCl}$ treated plants was assayed for the activity of P5CS (a) and catalase (b). The individual columns represent the mean specific activity (Unit $\mathrm{mg}^{-1}$ protein) value of at least 3 replicate studies. The vertical bars represent standard deviation. The mean specific activity values (columns) of P5CS or catalase marked with at least one common alphabet are not different significantly from each other at $\mathrm{p} \leq 0.05$, as found by Duncan's multiple range test for unequal sample size. Catalase extracted from the leaves of the control (C) and $425 \mathrm{mM} \mathrm{NaCl}$ treated (T) plants was loaded and run on native gel and stained for in-gel activity (c). The staining shows noticeable increase in the activity of the enzyme in response to the $\mathrm{NaCl}$ treatment. 


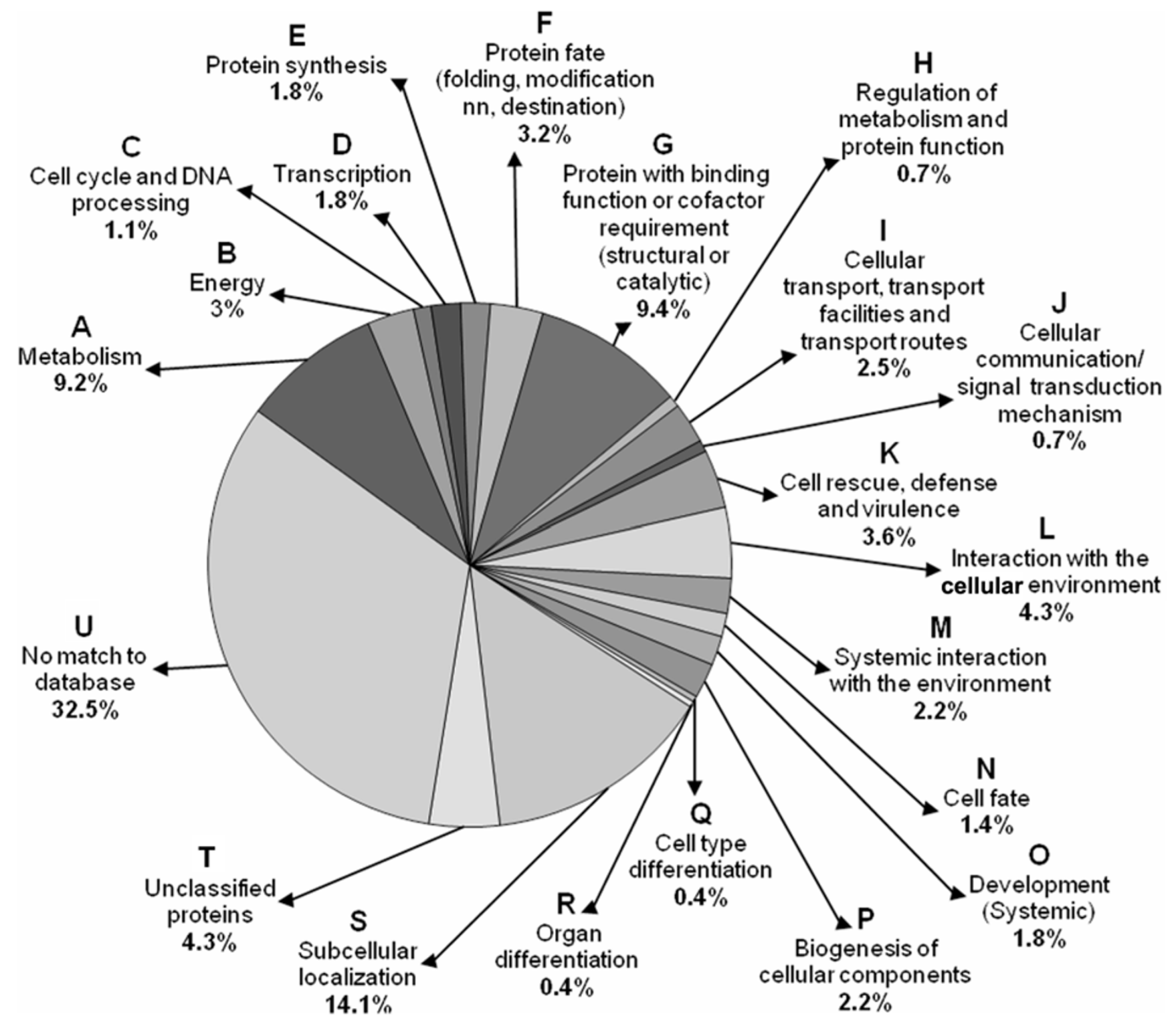

Figure 6

Functional categorization of the unigenes. The unigenes ( 167 numbers) found to be overexpressing in response to salt treatment in the present study were grouped into 19 functional sub-categories (A-S) under 6 main functional categories, namely metabolism (sub-category A-B), information pathways (sub-categories $C-H$ ), transport (sub-category I), perception and response to stimuli (sub-categories J-M), developmental processes (sub-categories $\mathrm{N}-\mathrm{R}$ ) and subcellular localization (sub-category S). Experimentally uncharacterized proteins were put into the sub-category $T$ (representing unclassified/unnamed proteins) and $U$ (representing protein with no match in the database). The percentage of the total unigenes representing a subcategory is given against it.

zation with the radiolabelled reverse subtracted SSH cDNA, nevertheless, revealed that these clones (ESTs) actually represented the genes overexpressing in response to the $\mathrm{NaCl}$ treatment (Fig. 3). The Northern blot hybridization also revealed that the SSH process was in fact dependent on the expression level of a gene, as the genes showing high ESTs redundancy showed greater hybridization signal than those showing low ESTs redundancy (Fig. 3, Table 2). Expression analysis of a few genes by qRT-PCR also confirmed the same; the $\mathrm{NaCl}$-induced changes in the transcript levels of the selected genes (Fig. 4) quite paralleled their ESTs redundancy (Table 2 and 3). Besides, the 


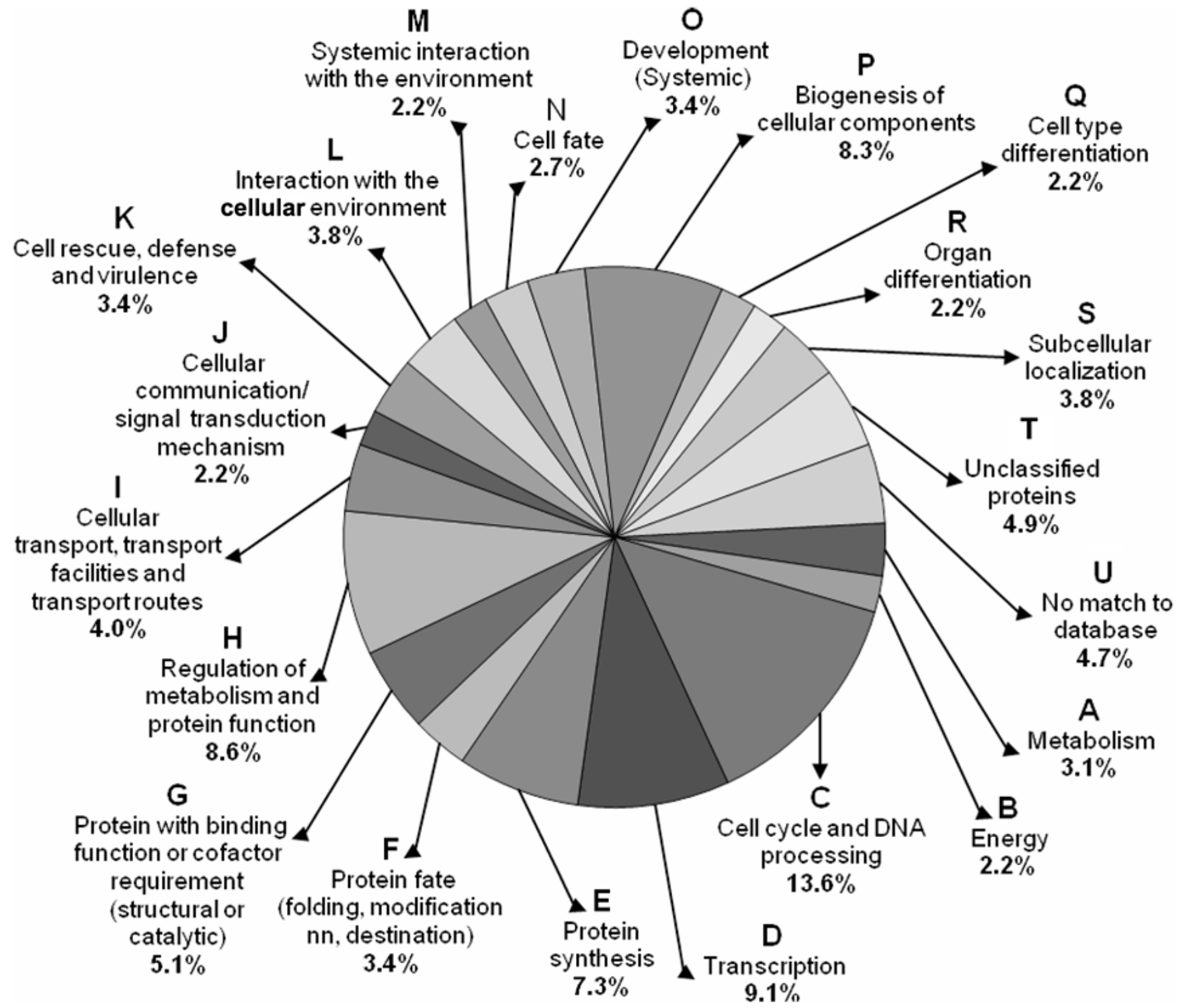

Figure 7

ESTs redundancy in individual functional categories/sub-categories. Functional categorization of the unigenes is same as in Fig. 6. The percentage value against each sub-category represents EST redundancy (in\%) in that particular group, which was calculated as the percentage of fraction of the number of ESTs representing the group/total number of ESTs.

qRT-PCR analysis also revealed that although the ESTs of the genes like P5CS and Cat were present in very low redundancy, their expression in response to the $\mathrm{NaCl}$ treatment had in fact increased by more than four fold. Hence, the genes showing low overexpression in response to a stress application may not find representation in the forward SSH cDNA library. It is also possible that the cDNAs of certain gene, present in high amount in both the 'Driver' and the 'Tester' cDNA population, may not be subtracted properly from the 'Tester' cDNA population in two rounds of hybridization with the 'Driver' cDNA, and thus the gene may find representation in the forward SSH cDNA library without actually overexpressing in response to a stress application [19].

The overexpression of as many as 167 unigenes while suggested involvement of a large number of genes in the salt tolerance process, contig EST redundancy of $81.8 \%$ indicated the possibility of discovery of more such genes, particularly that of the low abundance proteins, on continued cloning and sequencing of the forward $\mathrm{SSH}$ cDNA library. Moreover, more than $30 \%$ of the unigenes 
were novel, not reported before, and in addition approximately $4 \%$ were found to be producing proteins of unknown function (Table 1, Fig. 6, 7). These transcripts might represent important genes specific to salt tolerance. Although the EST redundancy of the genes in these groups is not high (Fig. 7), their importance in salt tolerance processes cannot be ignored (Fig. 7). The nucleotide and the corresponding amino-acid sequence data revealed that several clones isolated in this study, marked ' $b$ ' in Table 2 and 3, and in the supplementary table (see Additional file 1), were significantly homologous to the salt stress-regulated genes/proteins reported for various plant species. Other proteins are not reported to be saltinduced.

The PCR-SSH has revealed overexpression of as many as twenty four transcription factors in tomato in response to $\mathrm{NaCl}$-stress [18]. Using the same technique, Sahi et al. [19], however, has reported differential expression of genes of only two transcription factors, EREBP (ethylene responsive element binding protein) and $\mathrm{Zn}$-finger $(\mathrm{ZnF})$ protein, in two rice varieties in response to salt treatment. Our experiment on the other hand shows overexpression of the genes of six transcription factors in the test plant in response to the $\mathrm{NaCl}$ treatment (Table 2). The variation obtained could be species dependent. Nonetheless, the overexpression of the genes encoding EREBP and $\mathrm{ZnF}$ transcription factors are common among the three studies, suggesting important role of these proteins in the salt tolerance processes. EREBPs, currently known as ERE binding factor (ERF) proteins [50] belongs to a family of plant specific transcription factors characterized by the presence of 60 amino acid highly conserved ERF/AP2 (APETLA2) DNA binding domain. A number of genes, including those encoding pathogenesis-related and antifungal proteins, are induced by various forms of biotic and abiotic stresses, such as pathogen attack, wounding, $\mathrm{UV}$ radiation, high or low temperature, drought and $\mathrm{NaCl}$ $[50,51]$ mediated by ethylene produced in response to these stresses [51]. In addition, many of these have been found to contain ethylene responsive element (ERE), a cis acting element identified as GCC box for the interaction with ERF [52]. Certain Arabidopsis ERFs have also been reported to be induced by abiotic stresses, such as salinity, independent of ethylene signal transduction [50]. Enhanced expression of S-adenosyl-L-methionine synthase (SAMS) in the present case although indicated ethylene synthesis (Fig. 2) and ethylene dependent accumulation of ERF protein, the accumulation of ERF protein was most likely independent of the ethylene signal transduction. This is because there occurred no enhancement in the expression of ACC synthase (S-adenosyl-L-methionine methylthioadenosine-lyase) gene required for the conversion of S-adenosylmethionine to ACC (1-aminocycloropane-1-carboxylic acid), a rate lim- iting step in ethylene synthesis [53]. The increase in SAMS could be required to take care of the requirement of S-adenosylmethionine (SAM) for other biochemical reactions as the compound is the major methyl donor in plants and is used as a substrate for many biochemical pathways [54], involved in methylation reactions that modify lipids, proteins, and nucleic acids [53].

As for ethylene, no genes were identified in the forward SSH cDNA library that could be involved in the synthesis of jasmonic acid (JA) or methyl jasmonate (MeJA) from linolenic acid [55]. This is despite the fact that the forward SSH cDNA library showed the presence of ESTs for two isoforms of the gene encoding JAIP with a combined redundancy of as high as $10.49 \%$ (Table 1, Fig. 3, 4). Besides being induced by JA, a few JAIPs have also been reported to be induced by drought and salt [56,57]. The promoter of none of the genes encoding JAIPs has so far been studied. However, a jasmonate (and elicitor) responsive cis element (JERE) containing a GCC motif has been identified in the terpenoid involved alkaloid (TIA) biosynthetic gene strictosidine synthase, Str [58], which is recognised by a AP2 domain containing transcription factor ORCA2 (Octadecanoid-responsive Catharanthes AP2), similar to ERF, but its synthesis is induced by MeJa as elicitor instead of ethylene [58]. The involvement of the AP2domain family members in both ethylene and JA signalling suggest that ethylene and JA may crosstalk via these transcription factors. Moreover, recently transcription factors like JERF1 (Jasmonate and ethylene response factor 1) and Tsil1 (Tobacco stress-induced gene 1) induced by $\mathrm{NaCl}$, ethylene and JA have been discovered [49,59]. Besides binding to GCC box, these transcription factors also bind to dehydration responsive element (DRE)/Crepeat (CRT) involved in drought, salt and cold stress responses [60]. This expands the horizon of the crosstalk not only between ethylene and JA, but also among the other abiotic stresses, dependent or independent on ethylene/JA signalling for biological response.

The homeodomain zipper (HDZip) genes, ATB1 and HDZ3, were among the highest expressed transcription factors, which is not only reflected from their ESTs redundancy (Table 2), but also from the Northern blot result (Fig. 3). The combination of a homeodomain and a leucine zipper motif is unique to plant kingdom, suggesting that the HDZip genes may be involved in regulation of developmental processes specific to plants [61]. The functional information available on HDZip genes suggest that at least some of these genes are involved in mediating the effect of external conditions to regulate plant growth and development [62]. Several A. thaliana HDZip genes, like ATHB-6, -7 and -12 have been reported to be involved in abscisic acid (ABA) related response, including water deficit $[63,64]$. Several others, like ATHB-7, -12, -6, -21, -40 
and -53 , have also been reported to be overexpressed upon $\mathrm{NaCl}$ treatment, besides ABA treatment, particularly ATHB7 and -12, which showed 12 to 25 times upregulation [65]. However, ATHB1, to which the present HDZip finds maximum homology, have been found to be down regulated upon $\mathrm{NaCl}$ treatment [62]. The response of a member of a family of genes to the external environment could be, however, a species-specific phenomenon as CPHB-6 and CPHB-7 (Craterostigma plantagineum HDZip genes) upregulated upon ABA treatment [66], also finds maximum homology with ATHB-1. Hence, the HDZip genes overexpressed in the present case with a combined ESTs redundancy of $7.52 \%$ could be very important from the point of view of salt tolerance in plants.

The role of the other transcription factors in salt tolerance processes may not be ruled out as the genes of at least two more of them, $\mathrm{C} 2 \mathrm{H} 2$ zinc finger $(\mathrm{C} 2 \mathrm{H} 2-\mathrm{ZnF})$ and white collar (WC1), were overexpressed (Table 2). Among them, the $\mathrm{C} 2 \mathrm{H} 2$ type zinc finger protein with 176 members in $A$. thaliana [67] and 189 members in O. sativa [68], constitute one of the largest families of transcriptional regulators in plants. These are mostly plant specific, and synthesis of many of them has been found to be enhanced under salt [69-71] and other environmental stresses $[70,71]$. The importance of the protein in salt tolerance is also substantiated from the fact that tobacco plant transgene for $\mathrm{C} 2 \mathrm{H} 2-\mathrm{ZnF}$ (ZFP182, overexpressing in rice under salt stress) showed increased tolerance to salt stress [69]. With regard to WC-1, however, no report is available so far indicating its possible involvement in salt or abiotic stress tolerance. The protein is only known to mediate blue-light and circadian response [72]. The gene has so far not been found to be overexpressing under salt or other environmental stresses. Besides, the overexpression of the gene in Neurospora crassa does not result in any upregulation of the genes reportedly involved in salt or abiotic stress tolerance [72]. There is also no report of any abiotic factor accelerating accumulation of pasticcino-1 (PSA1), which regulates the function of NAC-like transcription factors by controlling its targeting to nucleus [73]. However, the NAC family of transcription factors, which is one of the largest transcription factor families in plant genomes, have not only been implicated in plant development $[73,74]$, but also in various abiotic stress responses [75]. Hence, it is plausible that PSA1 might be important from the point of view of salt tolerance depicting that a lots of cellular changes might be necessary for a plant to grow and perform under salt stress.

Overexpression of the genes encoding protein with various functional domains, such as CBS, F Box, C2 and C3H4 (Table 2) mediating important biochemical processes, mainly protein modification, degradation and membrane trafficking of proteins, is suggestive of their important role in adaptation of cells to $\mathrm{NaCl}$ enriched environment. In this regard, peroxin (PEX), a protein containing C3H4 Zn-RING finger, has been found to be involved in biogenesis of peroxisomes [76] important for not only carrying out fatty acid $\beta$-oxidation for energy generation, but also for protecting photo-damage of the photosynthetic machinery by carrying out photo-respiration. Besides, the organelle also harbour an antioxidant enzyme, catalase, required for eliminating $\mathrm{H}_{2} \mathrm{O}_{2}$ generated in plants under metabolic stress induced by $\mathrm{NaCl}$ [20], which otherwise would lead to oxidative damage to the cells. A RING finger containing protein (Rbx1) also forms a part of ubiquitin-proteosome system responsible for degrading the regulatory and misfolded proteins [77]; Rbx1 mediates binding of ubiquitin carrier protein (E2) to the multi-subunit ligase (E3) comprising of Skp1, culling1 and F-box protein (SCF), and the F-box subunit of E3 then recruits the protein to be poly-ubiquitinated and subsequently degraded $[77,78]$. Overexpression of the genes encoding proteins with $\mathrm{C} 3 \mathrm{H} 4$ and F-box motif in the plant in response to $\mathrm{NaCl}$ stress thus indicated enhanced synthesis of regulatory proteins, which are possibly destined to be degraded after their role in the adaptive processes are over.

The precise function of CBS (Cystathione- $\beta$-synthase) domain protein is yet to be understood, although thought to be regulatory. Overexpression of the gene encoding CBS domain containing protein and its presence in AMP activated protein kinase (AMPK), the cellular energy sensor, nevertheless, does suggest that salt adaptation could be linked to energy metabolism. In fact, it has been reported that CBS domain in AMPK has greater affinity for AMP than for ATP, and as the cellular energy content drops (low ATP, high AMP), binding of AMP to CBS domain of AMPK facilitates its phosphorylation making the enzyme active [79]. Once activated, AMPK drives the metabolic pathway towards ATP accumulation [79]. Besides, CBS domain is also present in plants in various chloride channels, which open upon binding of ATP to the domain, and thus it could be important from the point of view of regulation of membrane potential, $\mathrm{Cl}^{-}$ homeostasis and osmotic adjustment in plants under $\mathrm{NaCl}$ stress [80].

The overexpression of the genes encoding various transcription factors under $\mathrm{NaCl}$ stress in S. maritima is no doubt suggestive of great metabolic changes that might be occurring in plants depending upon their need for survival and growth under salt stress. However, these changes are not possible until the stress signal is perceived. This is supported in part by the overexpression of the gene encoding protein with $\mathrm{C} 2$ domain, a $\mathrm{Ca}^{2+}$ binding motif. Besides having affinity for $\mathrm{Ca}^{2+}, \mathrm{C} 2$ domain also displays remarkable property of recruiting a variety of other lig- 
ands and substrates, such as phospholipids and inositol phosphate [81]. Multiple copies of C2 domains have been identified in a growing number of eukaryotic signalling proteins that interact with cellular membranes and mediate a broad array of critical processes, including membrane trafficking, activation of GTPase for vesicular trafficking, control of protein phosphorylation and generation of lipid second messenger involved in signal transduction $[81,82]$. The $\mathrm{Ca}^{2+}$-dependent tolerance of plants to $\mathrm{NaCl}[20,83]$ could in fact be a result of enhanced synthesis of $\mathrm{Ca}^{2+-b i n d i n g ~ d o m a i n ~ c o n t a i n i n g ~ p r o t e i n s . ~ H o w-~}$ ever, no known Ca-binding proteins, like $\mathrm{Ca}^{2+}$ calmodulin dependent protein kinase PsCCaMK, the Arabidopsis protein AtPC1, the membrane associated protein in rice OsEFA27 and Arabidopsis RD20, etc. was found to be overexpressed in the present case. The stress signal perception might also be G-protein mediated as overexpression of the gene encoding the protein (Transducin) was observed under $\mathrm{NaCl}$ stress in the present case; the involvement of G-protein in transduction of environmental signal is well documented [84]. However, none of the effectors in G-protein signalling was found to be overexpressed. The appearance of various phosphatases and kinases (Table 2, see Additional file 1), nevertheless, does suggest that many changes in the metabolic processes in response to external or internal signals must be mediated by protein phosphorylation and dephosphorylation.

Besides phosphorylation, O-linked $\quad \beta$-N-acetylglucosamine (O-GlcNAc) modification of proteins could be abundant in S. maritima under $\mathrm{NaCl}$ stress, as it appears from the overexpression of O-GlcNAc transferase (OGT) gene (Table 2), and hence this could be an important biochemical event in the salt tolerance process. A large number of nuclear and cytosolic proteins are O-GlcNAc modified, and has been reported to affect stability of proteins and their sub-cellular localization [85]. One mechanism by which O-GlcNAc addition affect the changes in protein activity is through competition between O-GlcNAcylation and phosphorylation for the modification of serine/threonine residues. In fact, reciprocal phosphorylation/O-GlcNAcylation of specific amino acid has been demonstrated for several proteins, including the transcription factor, c-myc, and the reciprocal modification was found to differentially affect the activities of these proteins [86]. However, not all the substrate proteins are regulated via reciprocal phosphorylation/O-GlcNAcylation. In some cases, O-GlcNAc addition may directly affect the protein activity [87]. Although there is no report of OGT overexpression under any environmental stress, OGT activity has been found to be essential for plant survival [87].

The salt adaptive metabolic changes could be mediated by the heat shock protein HSP70, a well known molecular chaperon. This is reflected from the overexpression of the genes encoding $\mathrm{Bcl} 2$ binding $\mathrm{BAG}$ and DnaJ proteins (Table 2), which physically interact with HSP70 $[88,89]$. DnaJ like proteins are involved in a variety of processes including protein folding, protein partitioning into organelles, signal transduction and targeted protein degradation. Moreover, the DnaJ domain of the protein has especially been shown to interact directly with HSP70, thereby regulating its ATPase activity, which affects protein binding and folding [89]. Similar to DnaJ protein, BAG protein also has a conserved domain (BAG domain) to interact with the heat shock protein (HSP70/HSC70). Hence, the BAG protein might also be involved in protein folding and maturation [90]. The increased synthesis of BAG protein protects various cell types from heat-induced apoptosis, possibly through interaction with HSP70 and HSP40 [91].

In addition to the post translational events, pre-translational processes like mRNA and tRNA processing, and the translational event itself appear to be greatly changed or adjusted to suit the requirement demanded by salt adaptive physiological processes. This is evident from the significant increase in pre-mRNA splicing factor, $60 \mathrm{~S}$ ribosomal P0 protein, appr-1p processing enzyme family protein, eukaryotic elongation factor $1 \mathrm{~A}$, translation initiation factor $2 \mathrm{~B}-\beta$ sub-unit and valyl-tRNA. However, little is known about the role of these proteins in salt adaptation, or abiotic stress adaptation in general.

At the physiological level, the $\mathrm{NaCl}$ adaptive response was highly visible in terms of overexpression of the genes of many enzymes related to the synthesis and accumulation of glycinebetaine (Table 3). The most important among them being PEAMT mediating the conversion of phosphoethanolamine to phosphocholine, which is either dephosphorylated to form choline directly [92] or first incorporated into phosphatidylcholine and then metabolized to choline [93] (Fig. 2). Primarily the synthesis of choline occurs following the route phospho-ethanolamine (P-EA) to phospho-choline, P-choline (bold arrows, Fig. 2). However, the route P-EA to phosphatidylcholine, Ptd-choline (normal arrow, Fig. 2) also contributes substantially to choline synthesis depending upon the species [94]. The synthesis of the compound by other routes (broken arrows, Fig. 2) is also possible [94]. The choline produced in the cytoplasm is transported to the chloroplast where it is converted to glycinebetaine by the reactions catalyzed sequentially by choline monooxygenase $(\mathrm{CMO})$ and betainealdehyde dehydrogenase (BADH). Thus, PEAMT is although not directly involved in the synthesis of glycinebetaine, the enzyme appears to be very important in the biochemical pathways of synthesis of the osmoticum. The activity of PEAMT has been reported earlier to be greatly enhanced in the betaine accumulating 
halophyte Atriplex nummularia [95] and glycophyte spinach [92] by salt stress. These, together with the overexpression of PEAMT in the present case with high ESTs redundancy (Table 3 ) suggest that increased synthesis of choline could be highly essential for the survival of plants under salt stress, particularly those accumulating glycinebetaine, and that $S$. maritima might be a glycinebetaine accumulating halophyte. However, no overexpression of the gene encoding $\mathrm{BADH}$, the enzyme catalysing conversion of betainealdehyde to glycinebetaine (Fig. 2), the final step of glycinebetaine synthesis, was seen in the plant in response to the $\mathrm{NaCl}$ treatment (Fig. 4), although this has been reported for terrestrial glycophyte as well as halophyte $[96,97]$. This could be because the availability of choline is probably more important for the accumulation of glycinebetaine than the amount of the enzymes catalysing the conversion of choline to glycinebetaine, i.e. choline monoxygenase (CMO) and BADH (Fig. 2). The fact is substantiated from the observation that the supply of exogenous choline leads to glycinebetaine synthesis even in the plants not accumulating glycinebetaine naturally, like Arabidopsis thaliana, Brassica napus and Nicotiana tobacum [98]. Moreover, modelling of the labelling kinetics of choline metabolites upon supply of ${ }^{14} \mathrm{C}$-choline demonstrated that choline import into chloroplast indeed limited its flux to glycinebetaine [99]. Hence, it was postulated that a high-activity choline transporter in the chloroplast envelope could be an integral part of glycinebetaine synthesis pathway in the species that accumulate the compound naturally [99]. The overexpression of three isoforms of choline transporter gene, each with high EST redundancy, in the present study appears to support the hypothesis.

The fact that choline synthesis is really enhanced upon salt treatment is supported from the enhancement in the expression of the gene encoding SAM synthesizing enzyme, S-adenosylmethionine synthase, SAMS (Table 3, Fig. 2), which uses methionine and ATP as substrates. SAM is consumed in the glycinebetaine synthesis pathway for SAM-dependent methylation of ethanolamine (EA) or phosphoethanolamine (P-EA) in successive steps to produce choline, phosphocholine or phosphatidylcholine (Fig. 2). Besides, SAM is an essential substance for the living cells as a methyl group donor and as a precursor in ethylene biosynthesis catalyzed by ACC synthase and ACC oxidase (Fig. 2) $[53,100]$. Hence, maintaining a considerable pool of SAM by enhancing the rate of its synthesis must be essential when the physiological condition so demand, as in the case of glycinebetaine accumulation under salt stress. In fact, it has been observed that in halophyte Atriplex nummularia accumulating glycinebetaine under salt stress, the transcript levels of SAMS co-regulates with that of PEAMT in response to varying salinity level [95]. The present work thus indirectly suggests that while going for the development of transgenic plant for enhanced accumulation of glycinebetaine, the attention should be focused on increasing the level of choline and its transport to chloroplast. Attention should also be paid to the fact that the transfer of the methyl group from SAM generates S-adenosyl-L-homocysteine (SAH), which is a potent inhibitor of SAM dependent methyltransferases. Hence, SAH should be hydrolysed or removed, and this is done by S-adenosylhomocysteine hydrolase (SAHH), breaking it into homocysteine and adenosine [101]. The overexpression of $S A H H$ in $S$. maritima under salt stress in the present case is an indication that the plants accumulating glycinebetaine should overcome SAH accumulation, and that the plants transgenic for enhanced production of choline should also show enhanced expression of $S A H H$.

Besides glycinebetaine, proline is another osmoticum widely reported to accumulate in plants under salt stress. However, the report of accumulation of both glycinebetaine and proline in a plant in response to salt stress is limited [102]. The overexpression of the gene encoding P5CS (Table 3), the enzyme catalysing the conversion of $\Delta^{1}$-pyrroline-5-carboxylate to proline, the final step in the conversion of glutamate to proline, nevertheless, does suggest that proline, in addition to glycinebetaine, might be accumulating in the plant under $\mathrm{NaCl}$-stress. This may in fact be the requirement as the accumulation of glycinebetaine remains restricted to the chloroplast (Fig. 2), and hence the osmotic adjustment of the cytosol might be achieved by the accumulation of proline. Significant increase in the activity of P5CS (Fig. 5a), besides the expression of its gene (Fig. 3,4), also indicated possible accumulation of proline in the plant in addition to glycinebetaine upon salt treatment.

Although the maintenance of cellular ionic homeostasis has been emphasized for the survival of organism, especially under ionic stress [7], no overexpression of the genes of any known cation transporters, particularly of the alkali cations, was observed in the present study, except of a putative $\mathrm{Na}^{+} / \mathrm{H}^{+}$antiporter of low $\mathrm{E}$ value (Table 3 ). The finding is in contrast to the report of overexpression of $\mathrm{Na}^{+} / \mathrm{H}^{+}$antiporter gene in several plant species under salt stress $[7,8]$. Moreover, no Ca-binding protein or protein kinase was identified in the present study, in contrast to the SSH study in tomato [18], suggesting the absence of the SOS (salt overly sensitive) signalling pathway of $\mathrm{Na}^{+}$ efflux in the halophytes like S. maritima. Highly enhanced expression of the genes encoding at least two proteins (FC932784 and FG228211) finding high homology with the proteins conceptually translated as cation-efflux transporters from A. thaliana genome database, nevertheless, does suggest important role of cation efflux in salt toler- 
ance, although the ion(s) they transport remains to be identified.

Several genes having no known relationship with salt tolerance were found to be overexpressing in the plant in response to the salt treatment. The two well known among them are that encoding CCL (CCR-like, cold circadian rhythm-RNA binding like) protein and carbonic anhydrase (CA). CCL gene encodes highly unstable mRNA, the stability being regulated by circadian clock [103]. The transcript of this gene is significantly more stable in the morning than in the afternoon [103]. However, the EST redundancy of the CCL gene (Table 3) in the present study indicated high accumulation of transcripts of the gene even in the evening (the plants for the isolation of RNA were harvested in the evening). Hence, it appears that the salt treatment either had increased the stability of the CCL transcripts or had enhanced the expression of the gene in the plant. Although the role of the RNA binding proteins in posttranscriptional regulation of gene function, critical for eukaryotic growth and development, is well documented [104], expression of none of the genes encoding these proteins, including $C C L$, has been reported to be affected by salt treatment. The physiological function of carbonic anhydrase on the other hand is well known, facilitating $\mathrm{CO}_{2}$ availability for photosynthesis in $\mathrm{C}_{4}$ and submerged aquatic plants [105107]. The expression of its gene has also been reported to be highly enhanced in plants in response to salt treatment [29]. Besides, Arabidopsis plant transgenic for rice carbonic anhydrase (OsCA1) has been demonstrated to show greater salt tolerance than the wild type at the seedling stage [29]. However, any physiological or biochemical role of the enzyme in salt tolerance is yet to be established, especially in the non-aquatic angiosperm where the availability of $\mathrm{CO}_{2}$ is not influenced by salinity. The tolerance of Dunaliella salina, a unicellular alga, to nearly saturating $\mathrm{NaCl}$ concentration, nonetheless, has been suggested to be in part due to increased accumulation of a halophilic plasma membrane CA isoform. The enzyme shows maximum activity at much higher $\mathrm{NaCl}$ concentration and is much more resistant to inhibition by salt than the enzyme isolated from the salt-sensitive alga Chlamydomonas reinhardtii; the unique characteristics of $D$. salina carbonic anhydrase potentially enable the enzyme to optimise inorganic carbon utilization in high salinities [105].

Xyloglucan endotransglycosylase/hydrolase $(X T H)$ and expansin-3, both involved in cell wall metabolism, are also among the genes that have no biochemically or physiologically known relationship with salt tolerance, but were overexpressed upon salt treatment of the plant in this study (Table 3 ). One of them, XTH, a glucan endo1,3 - $\beta$-glucosydase, has also been reported to be greatly overexpressed in tomato upon salt treatment [18]. XTH catalyses endo cleavage of xyloglucan polymers and subsequent transfer of the newly generated reducing ends to other polymeric or oligomeric xyloglucan molecules and thereby participates in cell wall formation and elongation [108]. Expansin-3 on the other hand belongs to a group of extracellular non-enzymatic cell wall protein, which loosens the linkage between cellulose microfibrils by modifying the cell wall matrix in terms of increasing the mobility of the constituent matrix polymers [109]. The modification allows the cell wall to yield to the tensile stress created in the wall by the turgor pressure. Enhanced expression of XTH and expansin-3 in the present study seems to be in agreement with the visibly healthy growth and flaccid leaves of the plant grown in the saline medium than that grown without salt. However, no gene encoding expansin has so far been reported to be overexpressing in response to salinity. The maintenance of a greater leaf turgidity in the plant grown on salt than that grown without salt could be by accumulation of osmolytes, as discussed above.

An important physiological event that is not found in animals is photorespiration, which occurs in many plants upon their illumination leading to breakdown of rubisco1-5-biphosphate and synthesis of glycolic acid in the chloroplast. The glycolic acid produced is oxidized to glyoxalic acid in the peroxisomes with concomitant generation of $\mathrm{H}_{2} \mathrm{O}_{2}$. Overexpression of the gene encoding glycolate oxidase (see Additional file 1) does suggest enhancement in photorespiration, and catalase (Cat) is probably synthesized at enhanced rate (Fig. 5b, c, see Additional file 1) to protect the plant from oxidative damage by the accumulating $\mathrm{H}_{2} \mathrm{O}_{2}$. However, so far no relationship between photorespiration, or any of its components, and salt tolerance has been reported.

From the functional characterization of the unigenes, and redundancy of EST in the individual group, it appears that the proteins involved in cell cycle and DNA processing must be playing crucial role in salt adaptation as the redundancy of ESTs in the group was very high, 13.6\% (Fig. 7, sub-category C), despite very low contribution by the unigenes (Fig. 6). In the same way, the proteins involved in transcription (sub-category D) and protein synthesis (sub-category E) must also be very important in supporting the plant to go through the salt adaptation processes. This is because the transcription of the genes in these categories greatly increased upon $\mathrm{NaCl}$ treatment and contributed individually $7-9 \%$ of the ESTs population (Fig. 7) in contrast to each sub-category representing $1.8 \%$ of the total unigenes (Fig. 6). The role of the proteins regulating protein activity (sub-category $\mathrm{H}$ ), however, seems to be very important as the size of the ESTs of this category (Fig. 7) was more than 10 fold the size of the unigenes (Fig. 6) in the group. Besides, the ESTs of the pro- 
teins involved in signal transduction (sub-category J) also increased significantly compared to the size of the unigenes in the group. The results thus strongly suggest salt tolerance to be heavily dependent on the expression of the genes contributing to the information pathway (sub-categories $\mathrm{C}-\mathrm{H}$ ) of the plant protein functional catalogue involving protein controlling important cellular functions, such as cell cycle, transcription, protein synthesis, regulation of protein activity, etc. (Fig. 6, 7). Besides, the proteins involved in the developmental processes like cell type differentiation (sub-category Q), biogenesis of cellular components (sub-category P), etc. also appear to play important role in salt tolerance as the EST abundance of the related genes was found to be considerably high after those of the genes of the information pathway. Nonetheless, importance of the other proteins, particularly the unknown ones (sub-category U), cannot be ignored as many biochemical processes determining salt tolerance might be hidden in this pool, although the EST redundancy of the genes encoding these proteins was found to be much less than the size of unigenes in the group.

\section{Conclusion}

The present study thus reports for the first time differential expression of genes under salt stress in a natural halophyte. From the number of the unigenes showing overexpression in the plant in response to the salt application, it is highly convincing that the salt tolerance process is highly complex. However, even more puzzling is that a species differs greatly from the other in the genes that are salt regulated, as revealed by a comparative analysis of the present data with that available for rice [19] and tomato [18]. Therefore, it is desirable that more data are generated on the salt inducible/responsive genes of various plant species, particularly of the halophytes in order to identify the key elements involved in the salt tolerance processes, which is not possible with the currently available SSH cDNA libraries related to salt responsive genes. Nevertheless, it is quite convincing that the genes/proteins involved in the flow of information and developmental processes could be of much importance in salt stress response and adaptation of plants to saline environment. The number of genes possibly involved in salt tolerance can be narrowed down further if the SSH cDNA library data on salt inducible genes are available for a sufficiently large number of closely related halophytic species. Once this is achieved, the full length cDNA of the desired genes can be obtained easily and their specific functions in salt tolerance can be investigated further in suitable model systems using the available genetic transformation and gene knockdown/kockout technologies. Functional characterization of the proteins/genes that overexpress under salt stress, but have no known function, will be of particular importance in understanding the complex mechanism associated with salt tolerance. This will eventually enable the biotechnologists to target the right gene(s) for the genetic engineering of crop plants for improved salt tolerance. Nevertheless, the success of such effort will largely depend on the critical number of genes that must be genetically engineered to make a crop plant salt-resistant, besides on the effect of the transformation on the yield quantity and quality of the crop.

\section{Authors' contributions}

BPS conceived and coordinated the study. BBS carried out most of the molecular biology work. BPS did the enzyme activity studies. BPS and BBS jointly analysed the data and drafted the manuscript. BPS critically revised the manuscript for intellectual content. Both the authors read and approved the final manuscript.

\section{Additional material}

\section{Additional file 1}

BLASTX results of the ESTs sequences of $\mathrm{NaCl}$-induced genes in $\mathrm{S}$. maritima. mRNA was isolated from the leaves of young S. maritima plants exposed to $425 \mathrm{mM} \mathrm{NaCl}$ for $24 \mathrm{~h}$ (treated) and that not treated with $\mathrm{NaCl}$ (control). Forward SSH cDNA library, representing saltinduced genes, was constructed considering mRNA from the NaCl-treated plant as 'Tester' and that from control as 'Driver'. cDNAs of the library were cloned and transformed, and 502 ESTs from such clones were sequenced. ESTs sequences from the forward SSH cDNA library of S. maritima were grouped into singletons and contigs using TIGR Assembler http://nbc11.biologie.uni-kl.de/framed/Left/menu/auto/right/

tigr assembler and were termed as unigenes. The unigene sequences were blasted for homology search using BLASTX programme (default) at NCBI database. The search results are given. EST redundancy of each unigene is also given along with the average size of the ESTs constituting the unigene.

Click here for file

[http://www.biomedcentral.com/content/supplementary/14712229-9-69-S1.xls]

\section{Acknowledgements}

The authors thankfully acknowledge the laboratory facilities provided for the work by Dr. B. Ravindran, Director, Institute of Life Sciences, Bhubaneswar. Financial support for the work was received as extra-mural grant from DBT, New Delhi. BBS thankfully acknowledges the financial assistance received in the form of fellowship by UGC, New Delhi. The authors sincerely thank Dr. N. Tuteja, ICGEB, New Delhi for his constructive suggestions in writing the paper.

\section{References}

I. Mahajan S, Tuteja N: Cold, salinity and drought stresses: an overview. Arch Biochem Biophys 2005, 444: I39-158.

2. Koiwa $H$, Bressan RA, Hasegawa PM: Identification of plant stress-responsive determinants in Arabidopsis by large-scale forward genetic screens. J Exp Bot 2006, 57: I I I9- I I 28.

3. Munns R, James RA, Lauchli A: Approaches to increasing the salt tolerance of wheat and other cereals. J Exp Bot 2006, 57: 1025-1043.

4. Tripathi SB, Gurumurthi K, Panigrahi AK, Shaw BP: Salinity induced changes in proline betaine contents and synthesis in two 
aquatic macrophytes differing in salt tolerance. Biol Plant 2007 $5 \mathrm{I}: \mathrm{II} 0-\mathrm{II} 5$.

5. Vitart V, Baxter I, Doerner P, Harper JF: Evidence for a role in growth and salt resistance of a plasma membrane $\mathrm{H}^{+}$ ATPase in the root endodermis. Plant J 200I, 27:19I-20I.

6. Lin HX, Zhu MZ, Yano M, Gao JP, Liang ZW, Su WA, Hu XH, Ren $\mathrm{ZH}$, Chao DY: QTLs for $\mathrm{Na}^{+}$and $\mathrm{K}^{+}$uptake of the shoots and roots controlling rice salt tolerance. Theoretical and Applied Genetics 2004, 108:253-260.

7. Pardo JM, Cubero B, Leidi EO, Quintero FJ: Alkali cation exchangers: roles in cellular homeostasis and stress tolerance. J Exp Bot 2006, 57: 1181-1199.

8. Xia T, Apse MP, Aharon GS, Blumwald E: Identification and characterization of a $\mathrm{NaCl}$-inducible vacuolar $\mathrm{Na}^{+} / \mathrm{H}^{+}$antiporter in Beta vulgaris. Physiol Plant 2002, 116:206-2/2.

9. Shi H, Quintero FJ, Pardo JM, Zhu JK: The putative plasma membrane $\mathrm{Na}(+) / H(+)$ antiporter SOSI controls long-distance $\mathrm{Na}(+)$ transport in plants. Plant Cell 2002, 14:465-477.

10. Pedranzani H, Racagni G, Alemano S, Miersch O, Ramírez I, PeñaCortés H, Taleisnik E, Machado-Domenech E, Abdala G: Salt tolerant tomato plants show increased levels of jasmonic acid. Plant Growth Regulation 2004, 4 I: I 49- 158

II. Fricke W, Akhiyarova G, Wei W, Alexandersson E, Miller A, Kjellbom $\mathrm{PO}$, et al:: The short-term growth response to salt of the developing barley leaf. J Exp Bot 2006, 57:1079-1095.

12. Qiu QS, Guo Y, Dietrich MA, Schumaker KS, Zhu JK: Regulation of SOSI, a plasma membrane $\mathrm{Na}^{+} / \mathrm{H}^{+}$exchanger in Arabidopsis thaliana, by SOS2 and SOS3. Proc Natl Acad Sci USA 2002, 99:8436-844I.

13. Mahajan S, Pandey G, Tuteja N: Calcium and Salt Stress Signaling in Plants: Shedding Light on SOS Pathway. Arch Biochem Biophys 2008, 47I: | 46-158.

14. Demidchik V, Bowen HC, Maathuis FJ, Shabala SN, Tester MA, White PJ, Davies JM: Arabidopsis thaliana root non-selective cation channels mediate calcium uptake and are involved in growth. Plant J 2002, 32:799-808.

15. Xiong L, Schumaker KS, Zhu JK: Cell signaling during cold, drought, and salt stress. Plant Cell 2002, 14:SI65-SI83.

16. Mishra NS, Tuteja R, Tuteja N: Signaling through MAP kinase networks in plants. Arch Biochem Biophys 2006, 452:55-68.

17. Ma S, Gong $\mathrm{Q}$, Bohnert HJ: Dissecting salt stress pathways. J Exp Bot 2006, 57:1097-1107.

18. Ouyang B, Yang T, Li H, Zhang L, Zhang Y, Zhang J, Fei Z, Ye Z: Identification of early salt stress response genes in tomato root by suppression subtractive hybridization and microarray analysis. J Exp Bot 2007, 58:507-520.

19. Sahi C, Agarwal M, Reddy MK, Sopory SK, Grover A: Isolation and expression analysis of salt stress-associated ESTs from contrasting rice cultivars using a PCR-based subtraction method. Theor Appl Genet 2003, I06:620-628.

20. Rout NP, Shaw BP: Salt tolerance in aquatic macrophytes: possible involvement of the antioxidative enzymes. Plant Sci 200I, 160:415-423.

21. Parida $A K$, Das $A B$, Mohanty $P$ : Defense potentials to $\mathrm{NaCl}$ in a mangrove, Bruguiera parviflora: differential changes of isoforms of some antioxidative enzymes. J. Plant Physiol 2004 | 6 1:531-542.

22. Pareek A, Singla SL, Grover A: Immunological evidence for accumulation of two high-molecular-weight (104 and $90 \mathrm{kDa})$ HSPs in response to different stresses in rice and in response to high temperature stress in diverse plant genera. Plant Mol Biol 1995, 29:293-30I.

23. Swindell WR, Huebner M, Weber AP: Transcription profiling of Arabidopsis heat-shock proteins and transcription factors reveals extensive overlap between heat and non-heat stress response pathways. BMC Genomics 2007, 8:125.

24. Chourey K, Ramani S, Apte SK: Accumulation of LEA proteins in salt $(\mathrm{NaCl})$ stressed young seedlings of rice (Oryza sativa $\mathrm{L}$.) cultivar Bura Rata and their degradation during recovery from salinity stress. J Plant Physiol 2003, 160: I 165-I I74.

25. Moons A, Prinsen E, Bauw G, Motagu MV: Antagonistic effects of abscisic acid and jasmonates on salt stress-inducible transcripts in rice roots. Plant Cell 1997, 9:2243-2259.

26. Jeong MJ, Park SC, Byun MO: Improvement of salt tolerance in transgenic potato plants by glyceraldehyde-3 phosphate dehydrogenase gene transfer. Mol Cells 200I, I2:185-189.
27. Sawahel WA, Hassan AH: Generation of transgenic wheat plants producing high levels of the osmoprotectant proline. Biotechnol Lett 2002, 24:72I-725.

28. Sanan-Mishra N, Pham XH, Sopory SK, Tuteja N: Pea DNA helicase 45 overexpression in tobacco confers high salinity tolerance without affecting yield. Proc Natl Acad Sci USA 2005, 102:509-5I4.

29. Yu S, Zhang X, Guan Q, Takano T, Liu S: Expression of a carbonic anhydrase gene is induced by environmental stresses in rice (Oryza sativa L.). Biotechnol Lett 2007, 29:89-94.

30. Shi H, Lee BH, Wu SJ, Zhu JK: Overexpression of a plasma membrane $\mathrm{Na}+\mathrm{H}+$ antiporter gene improves salt tolerance in Arabidopsis thaliana. Nat Biotechnol 2003, $21: 81-85$.

31. Cuartero J, Bolarin MC, Asins MJ, Moreno V: Increasing salt tolerance in the tomato. J Exp Bot 2006, 57: 1045-1058.

32. Genoud T, Metraux JP: Crosstalk in plant cell signalling: structure and function of the genetic network. Trends Plant Sci 1999 , 4:503-507.

33. Chinnusamy V, Schumaker K, Zhu JK: Molecular genetic perspectives on cross-talk and specificity in abiotic stress signalling in plants. J Exp Bot 2004, 55:225-236.

34. Shinozaki K, Yamaguchi-Shinozaki K: Molecular responses to dehydration and low temperature: differences and cross-talk between two stress signalling pathways. Curr Opin Plant Biol 2000, 3:217-223.

35. Hasegawa PM, Bressan RA, Zhu JK, Bohnert HJ: Plant cellular and molecular responses to high salinity. Annu Rev Plant Physiol Plant Mol Biol 2000, 5 I:463-499.

36. Zhu JK: Salt and drought stress signal transduction in plants. Annu Rev Plant Biol 2002, 53:247-273.

37. Zhu JK: Regulation of ion homeostasis under salt stress. Curr Opin Plant Biol 2003, 6:44I-445.

38. Hasegawa PM, Bressan RA, Zhu JK, Bohnert HJ: Plant cellular and molecular responses to high salinity. Annu Rev Plant Physiol Plant Mol Biol 2000, 5 I:463-499.

39. Fernandez P, Di Rienzo J, Fernandez L, Hopp HE, Paniego N, Heinz RA: Transcriptomic identification of candidate genes involved in sunflower responses to chilling and salt stresses based on cDNA microarray analysis. BMC Plant Biol 2008, 8: I I

40. Zhang X-N, Qu Z-C, Wan Y-Z, Zhang H-W, Shen D-L: Application of suppression subtractive hybridization (SSH) to cloning differentially expressed cDNA in Dunaliella salina (Chlorophyta) under hyperosmotic shock. Plant Mol Biol Rep 2002, 20:49-57.

4I. Sambrook J, Fitsch E, Maniatis T: Molecular Cloning: A Laboratory Manual. Cold Spring Harbor Laboratory Press, Cold Spring Harbor, NY; 1989.

42. Pfaffl MW: A new mathematical model for relative quantification in real-time RT-PCR. Nucleic Acids Res 200I, 29:2002-2007.

43. Chilson OP, Kelly-Chilson AE, Scheinder JD: Pyrroline-5-carboxylate reductase in soybean nodules. Plant Physiol 1992, 99:119-123

44. Bradford MM: A rapid and sensitive method for the quantification of microgram quantities of protein using the principle of protein dye-binding. Anal Biochem 1976, 72:248-254.

45. Hayzer DJ, Leisinger T: The gen-enzyme relationships of proline biosynthesis in Escherichia coli. J Gen Microbiol 1980, I I 8:287-293

46. Chance B, Maehly AC: Assay of catalase and peoroxidase. In Methods in Enzymology Volume 2. Edited by: Clowick SP, Kaplan NO. New York: Academic Press; 1955:764-775.

47. Blis Cl: Stastistics in Biology: Statistical Methods for Research in the Natural Sciences Volume I. New York: McGraw-Hill Book Company; 1967.

48. Mittler R, Zilinskas BA: Detection of ascorbate peroxidase activity in native gels by inhibition of the ascorbate-dependent reduction of nitroblue tetrazolium. Anal Biochem 1993, 21 2:540-546

49. Zhang H, Huang Z, Xie B, Chen Q, Tian X, Zhang X, Lu X, Huang D, Huang R: The ethylene-, jasmonate-, abscisic acid- and $\mathrm{NaCl}$ responsive tomato transcription factor JERFI modulates expression of GCC box-containing genes and salt tolerance in tobacco. Planta 2004, 220:262-270.

50. Fujimoto SY, Ohta M, Usui A, Shinshi H, Ohme-Takagi M: Arabidopsis ethylene-responsive element binding factors act as transcriptional activators or repressors of GCC box-mediated gene expression. Plant Cell 2000, I 2:393-404. 
5I. O'Donnell PJ, Calvert C, Atzorn R, Wasternack C, Leyser HMO, Bowles DJ: Ethylene as a signal mediating the wound response of tomato plants. Science 1996, 274:1914-1917.

52. Sessa G, Meller Y, Fluhr R: A GCC element and a G-box motif participate in ethylene-induced expression of the PRB-Ib gene. Plant Mol Biol 1995, 28: I45-I53.

53. Wang KL, Li H, Ecker JR: Ethylene biosynthesis and signaling networks. Plant Cell 2002, I4:SI3I-SI5I.

54. Ravanel S, Gakiere B, Job D, Douce R: The specific features of methionine biosynthesis and metabolism in plants. Proc Natl Acad Sci USA 1998, 95:7805-78I2.

55. Koo AJ, Chung HS, Kobayashi Y, Howe GA: Identification of a peroxisomal acyl-activating enzyme involved in the biosynthesis of jasmonic acid in Arabidopsis. I Biol Chem 2006, 28 I:335 I I-33520.

56. Mason HS, Mullet JE: Expression of two soybean vegetative storage protein genes during development and in response to water deficit, wounding, and jasmonic acid. Plant Cell 1990 , 2:569-579

57. Shunsuke I, Kyoto K-N, Ken M, Atsushi M, Kenzo N: A major jasmonate-inducible protein of sweet potato, Ipomoelin, is an ABA-independent wound-inducible protein. Plant Cell Physiol 1997, 38:643-652.

58. Menke FL, Champion A, Kijne JW, Memelink J: A novel jasmonateand elicitor-responsive element in the periwinkle secondary metabolite biosynthetic gene Str interacts with a jasmonateand elicitor-inducible AP2-domain transcription factor, ORCA2. Embo J 1999, I 8:4455-4463.

59. Park JM, Park CJ, Lee SB, Ham BK, Shin R, Paek KH: Overexpression of the tobacco Tsi I gene encoding an EREBPIAP2-type transcription factor enhances resistance against pathogen attack and osmotic stress in tobacco. Plant Cell 200I, I 3:1035-1046

60. Stockinger EJ, Gilmour SI, Thomashow MF: Arabidopsis thaliana CBFI encodes an AP2 domain-containing transcriptional activator that binds to the C-repeat/DRE, a cis-acting DNA regulatory element that stimulates transcription in response to low temperature and water deficit. Proc Natl Acad Sci USA 1997, 94: 1035-1040.

61. Ariel FD, Manavella PA, Dezar CA, Chan RL: The true story of the HD-Zip family. Trends Plant Sci 2007, 12:419-426.

62. Henriksson $E$, Olsson AS, Johannesson $H$, Johansson $H$, Hanson J Engstrom P, Soderman E: Homeodomain leucine zipper class I genes in Arabidopsis. Expression patterns and phylogenetic relationships. Plant Physiol 2005, I39:509-5 I8.

63. Soderman E, Hjellstrom M, Fahleson J, Engstrom P: The HD-Zip gene ATHB6 in Arabidopsis is expressed in developing leaves, roots and carpels and up-regulated by water deficit conditions. Plant Mol Biol 1999, 40:1073-1083

64. Olsson AS, Engstrom P, Soderman E: The homeobox genes $A T H B I 2$ and $A T H B 7$ encode potential regulators of growth in response to water deficit in Arabidopsis. Plant Mol Biol 2004, 55:663-677.

65. Soderman E, Mattsson J, Engstrom P: The Arabidopsis homeobox gene $A T H B-7$ is induced by water deficit and by abscisic acid. Plant J 1996, 10:375-381.

66. Deng X, Phillips J, Meijer AH, Salamini F, Bartels D: Characterization of five novel dehydration-responsive homeodomain leucine zipper genes from the resurrection plant Craterostigma plantagineum. Plant Mol Biol 2002, 49:601-6I0.

67. Ciftci-Yilmaz S, Mittler R: The zinc finger network of plants. Cell Mol Life Sci 2008, 65: I 150-1 I60.

68. Agarwal P, Arora R, Ray S, Singh AK, Singh VP, Takatsuji H, Kapoor $\mathrm{S}$, Tyagi AK: Genome-wide identification of $\mathbf{C 2} \mathbf{H 2}$ zinc-finger gene family in rice and their phylogeny and expression analysis. Plant Mol Biol 2007, 65:467-485

69. Huang J, Yang X, Wang MM, Tang HJ, Ding LY, Shen Y, Zhang HS: A novel rice $\mathrm{C} 2 \mathrm{H} 2$-type zinc finger protein lacking $D L N$-box/ EAR-motif plays a role in salt tolerance. Biochim Biophys Acta 2007, I 769:220-227.

70. Xu S, Wang $X$, Chen J: Zinc finger protein I (ThZFI) from salt cress (Thellungiella halophila) is a Cys-2/His-2-type transcription factor involved in drought and salt stress. Plant Cell Rep 2007, 26:497-506.

7I. Sakamoto H, Maruyama K, Sakuma Y, Meshi T, Iwabuchi M, Shinozaki K, Yamaguchi-Shinozaki K: Arabidopsis Cys2/His2-type zinc-fin- ger proteins function as transcription repressors under drought, cold, and high-salinity stress conditions. Plant Physiol 2004, I 36:2734-2746.

72. Lewis ZA, Correa A, Schwerdtfeger C, Link KL, Xie X, Gomer RH Thomas T, Ebbole DJ, Bell-Pedersen D: Overexpression of White Collar-I (WC-I) activates circadian clock-associated genes, but is not sufficient to induce most light-regulated gene expression in Neurospora crassa. Mol Microbiol 2002, 45:917-931.

73. Smyczynski C, Roudier F, Gissot L, Vaillant E, Grandjean O, Morin H, Masson T, Bellec $Y$, Geelen D, Faure JD: The $\mathbf{C}$ terminus of the immunophilin PASTICCINOI is required for plant development and for interaction with a NAC-like transcription factor. J Biol Chem 2006, 28 I:25475-25484.

74. Xie Q, Frugis G, Colgan D, Chua NH: Arabidopsis NACI transduces auxin signal downstream of TIRI to promote lateral root development. Genes Dev 2000 I 4:3024-3036.

75. Hegedus D, Yu M, Baldwin D, Gruber M, Sharpe A, Parkin I, Whitwill S, Lydiate D: Molecular characterization of Brassica napus NAC domain transcriptional activators induced in response to biotic and abiotic stress. Plant Mol Biol 2003, 53:383-397.

76. Schumann U, Prestele J, O'Geen H, Brueggeman R, Wanner G, Gietl C: Requirement of the C3HC4 zinc RING finger of the Arabidopsis PEXI 0 for photorespiration and leaf peroxisome contact with chloroplasts. Proc Natl Acad Sci USA 2007, I04: I069-1074.

77. Kirk R, Laman H, Knowles PP, Murray-Rust J, Lomonosov M, Meziane el K, McDonald NQ: Structure of a conserved dimerization domain within the F-box protein $\mathrm{Fbxo7}$ and the PI3 I proteasome inhibitor. I Biol Chem 2008, 283:22325-22335.

78. Hershko A, Ciechanover A: The ubiquitin system. Annu Rev Biochem 1998, 67:425-479.

79. Ignoul S, Eggermont J: CBS domain: structure, function, and pathology in human proteins. Am J Cell Physiol 2005, 289:CI369-CI378.

80. Diedhiou CJ, Golldack D: Salt dependent regulation of chloride channel transcripts in rice. Plant Science 2005, I 70:793-800.

8I. Nalefski EA, Falke J]: The C2 domain calcium-binding motif structural and functional diversity. Protein Sci 1996, 5:2375-2390.

82. Yang W-Q, Lai Y, Li M-N, Xu W-Y, Xue Y-B: A novel C2-domain phospholipid-binding protein, OsPBPI, is required for pollen fertility in rice. Mol Plant 2008, I:770-785.

83. Colmer TD, Fan TW-M, Higashi RM, Lauchi A: Interactive effects of $\mathrm{Ca}^{2+}$ and $\mathrm{NaCl}$ salinity on the ionic relations and proline accumulation in primary root tip of Sorghum bicolour. Physiol Plant 1996, 97:421-424.

84. Assmann SM: $\mathbf{G}$ proteins $\mathbf{G o}$ green: a plant $\mathbf{G}$ protein signaling FAQ sheet. Science 2005, 3 | 0:7|-73.

85. Snow DN, Hart GW: Nuclear and cytoplasmic glycosylation. Int Rev Cytol 1998, I 81:43-74.

86. Chou TY, Hart GW, Dang CV: c-Myc is glycosylated at threonine 58, a known phosphorylation site and a mutational hot spot in lymphomas. I Biol Chem 1995, 270: | 896 I- | 8965.

87. Hartweck LM, Scott CL, Olszewski NE: Two O-linked $\mathbf{N}$ acetylglucosamine transferase genes of Arabidopsis thaliana L. Heynh. have overlapping functions necessary for gamete and seed development. Genetics 2002, I6 I: I279-1291.

88. Wang HG, Takayama S, Rapp UR, Reed JC: Bcl-2 interacting protein, BAG-I, binds to and activates the kinase Raf- I. Proc Natl Acad Sci USA 1996, 93:7063-7068.

89. Sedbrook JC, Chen R, Masson PH: ARGI (altered response to gravity) encodes a DnaJ-like protein that potentially interacts with the cytoskeleton. Proc Natl Acad Sci USA 1999, 96: II $140-1145$

90. Takayama S, Xie Z, Reed JC: An evolutionarily conserved family of Hsp70/Hsc70 molecular chaperone regulators. J Biol Chem 1999, 274:78|-786.

91. Zeiner M, Niyaz Y, Gehring U: The hsp70-associating protein Hap46 binds to DNA and stimulates transcription. Proc Nat Acad Sci USA 1999, 96:10194-10199.

92. Summers PS, Weretilnyk EA: Choline synthesis in spinach in relation to salt stress. Plant Physiol I993, I03:I269-I276.

93. McNeil SD, Rhodes D, Russell BL, Nuccio ML, Shachar-Hill Y, Hanson $A D$ : Metabolic modeling identifies key constraints on an engineered glycine betaine synthesis pathway in tobacco. Plant Physiol 2000, I 24: I53-162. 
94. Rhodes D, Hanson AD: Quarternary ammonium and tertiary sulfonium compounds in higher plants. Annu Rev Plant Physiol Plant Mol Biol I 993, 44:357-384.

95. Tabuchi T, Kawaguchi Y, Azuma T, Nanmori T, Yasuda T: Similar regulation patterns of choline monooxygenase, phosphoethanolamine $\mathbf{N}$-methyltransferase and S-adenosyl-L-methionine synthetase in leaves of the halophyte Atriplex nummularia L. Plant Cell Physiol 2005, 46:505-5I3.

96. Nakamura T, Yokota S, Muramoto Y, Tsutsui K, Oguri Y, Fukui K, Takabe T: Expression of a betaine aldehyde dehydrogenase gene in rice, a glycinebetaine nonaccumulator, and possible localization of its protein in peroxisomes. Plant J 1997, I I:I I I5-I I 20

97. Hibino T, Meng YL, Kawamitsu Y, Uehara N, Matsuda N, Tanaka Y, Ishikawa H, Baba S, Takabe T, Wada K, Ishii T: Molecular cloning and functional characterization of two kinds of betaine-aldehyde dehydrogenase in betaine-accumulating mangrove Avicennia marina (Forsk.) Vierh. Plant Mol Biol 200I, 45:353-363.

98. Huang J, Hirji R, Adam L, Rozwadowski KL, Hammerlindl JK, Keller WA, Selvaraj G: Genetic engineering of glycinebetaine production toward enhancing stress tolerance in plants: metabolic limitations. Plant Physiol 2000, I 22:747-756.

99. Nuccio ML, McNeil SD, Ziemak MJ, Hanson AD, Jain RK, Selvaraj G: Choline import into chloroplasts limits glycine betaine synthesis in tobacco: analysis of plants engineered with a chloroplastic or a cytosolic pathway. Metab Eng 2000, 2:300-3 I I.

100. Moffatt BA, Weretilnyk EA: Sustaining S-adenosyl-L-methionine-dependent methyltransferase activity in plant cells. Physiol Plant 200 I, I I 3:435-442.

10I. Pereira LA, Todorova M, Cai X, Makaroff CA, Emery RJ, Moffatt BA: Methyl recycling activities are co-ordinately regulated during plant development. J Exp Bot 2007, 58: I083-1098.

102. Carillo P, Mastrolonardo G, Nacca F, Parisi D, Verlotta A, Fuggi A: Nitrogen metabolism in durum wheat under salinity: accumulation of proline and glycinebetaine. Functional Plant Biology 2008, 35:412-426.

103. Lidder P, Gutierrez RA, Salome PA, McClung CR, Green PJ: Circadian control of messenger RNA stability. Association with a sequence-specific messenger RNA decay pathway. Plant Physiol 2005, I 38:2374-2385.

104. Lim MH, Kim J, Kim YS, Chung KS, Seo YH, Lee I, Kim J, Hong CB, Kim HJ, Park CM: A new Arabidopsis gene, FLK, encodes an RNA binding protein with $K$ homology motifs and regulates flowering time via FLOWERING LOCUS C. Plant Cell 2004, 1 6:731-740.

105. Fisher M, Gokhman I, Pick U, Zamir A: A salt tolerant membrane carbonic anhydrase is induced by salt in Dunaliella salina. J Biol Chem 1996, 27 I: I77I8-17723.

106. Thomas J, Bohnert JB: Salt stress perception and plant growth regulators in the halophyte Mesembryathemum crystallinum. Plant Physiol 1993, 103:1299-I304.

107. Hatch MD, Burnell JN: Carbonic anhydrase activity in leaves and its role in the first step in $\mathbf{C}_{4}$ photosynthesis. Plant Physiol 1990, 93:825-828.

108. Jan A, Yang G, Nakamura H, Ichikawa $H$, Kitano H, Matsuoka M, Matsumoto $\mathrm{H}$, Komatsu $\mathrm{S}$ : Characterization of a xyloglucan endotransglucosylase gene that is up-regulated by gibberellin in rice. Plant Physiol 2004, I36:3670-368I.

109. Cosgrove DJ: Loosening of plant cell walls by expansins. Nature 2000, 407:321-326.
Publish with Bio Med Central and every scientist can read your work free of charge

"BioMed Central will be the most significant development for disseminating the results of biomedical research in our lifetime. "

Sir Paul Nurse, Cancer Research UK

Your research papers will be:

- available free of charge to the entire biomedical community

- peer reviewed and published immediately upon acceptance

- cited in PubMed and archived on PubMed Central

- yours - you keep the copyright

Submit your manuscript here:

http://www.biomedcentral.com/info/publishing_adv.asp
BiolMedcentral 